線溶系及び Cholinestrase 系よりみたる特発性腎出血

（泌尿器科領域における線溶系の研究 第 2 報）

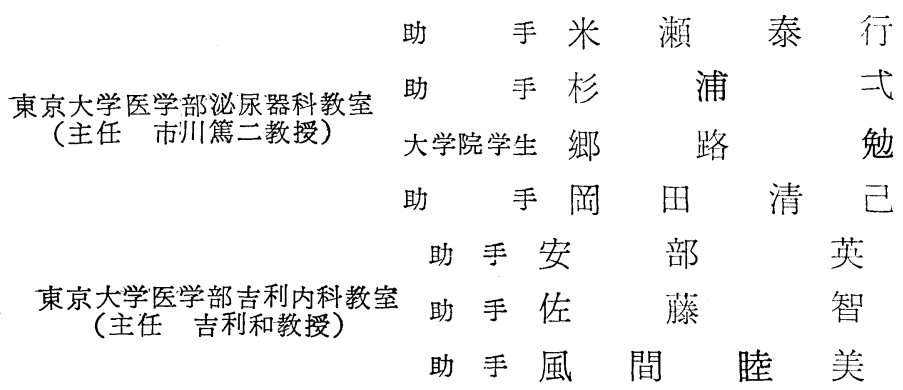

\title{
FIBRINOLYTIC ACTIVITY AND SERUM CHOLINESTERASE IN PATIENTS OF ESSENTIAL RENAL BLEEDING
}

\author{
Yasuyuki Yonese, Hajime Sugiura, Tsutomu Gōro and Kiyoki Ōkada \\ From the Urology Department, Medical Faculty, the University of Tokyo \\ (Director: Prof. T. Ichikawa) \\ Takeshi Abe, Akira Sato and Mutsuyoshi Kazama \\ From the Medical Department, Medical Faculty, the University of Tokyo
}

(Director: Prof. Y. Yoshitoshi)

特発性腎出血は Nitze, Mahlherbe, Legueu の時代 より多くの学者によりその原因究明が行われ，種々の病 因が挙げられている. 然し要的すると市川 (1960） ${ }^{44)}$ 述べたょうに,

1）病理組織学的に出血原因を究明できるもの.

（微細病巣よりの出血群）

2) 病理組織学的にも尚不明のもの. (原因不明の出血群)

の 2 群に分類できる. 臨床家の立場としてての両者を 病理組織学的に追求するととは不可能であり 1 の症候群 として解釈すべきであるが, 最近酥素学的な立場から本 疾患の病態生理の追求 が行われ原因不明の出血機序の 解明がされようとしている. 出血との関連に於て問題と されている楾維素溶解醭素 Plasmin 系とAcetylcholine-Cholinesterase 系の両者について検索したので報 告する.

〔I]統計学的考察：その詳細については著者の1 人杉浦 ${ }^{58)}$ が発表したところであるがそれを要約する已次 の如くである.
1）患者数：1957年 1 月より 1961年12月に至る5 年間 に当科を訪れ諸検查の結果特発性腎出血々診断された子 のは 419例 (入院加療11例外来治療 408例) で，乙の間 の外来患者総数は 23418 例であり本疾患汸約 $1.8 \%$ に相 当する。

2）性別及び年令別：男子 $64.2 \%$ ，女子 $35.8 \%$ で男子 は女子の約 2 倍に当る. 男子では最低 2 才最高78才であ り，女子では最低 5 才最高73才であるが男女を通じて 21才ないし40才に至る青壮年層に最も多く男子 132例 (49.1\%) 女子76例 (50.7\%), 合計 208 例 $(49.9 \%) て ゙$ 約半数字占めている.

3）患側別：膀胱鏡検查で患側を確認し得なかつた 2 08例 $(49.2 \%)$ を除くと男女ともに左側が右側の約 2 倍 で 419例中左側 113 例 $(32.1 \%)$ 右側68例 (17.4\%) 両 側10例 ( $2.5 \%)$ である.

4）発病の月及び季節別：患者が初めて血尿に気づい た時及び影微鏡的血尿患者ではその初䛦時の月を以て表 すと次の如くである。

3 月- 49 例（ $9.8 \%) ， 12$ 月- 46 例（ $9.2 \%), 11$ 月一 
39 例 ( $7.8 \%)$, 10月-37例 ( $7.4 \%), 8$ 月- 34 例 ( 6.8 $\%), 2$ 月及び 9 月- 33 例 $(6.6 \%), 5$ 月- 32 例 $(6.4$ $\%), 4$ 月- 31 例 ( $6.2 \%), 7$ 月- 29 例 ( $5.8 \%), 1$ 月及 び6月一28例 ( $5.4 \%)$ であり, 季節的にはそれ程差 は認められないが, 春一 112例 $(26.7 \%)$, 秋- 109例 $(26.0 \%)$, 冬 - 107 例 $(25.5 \%)$, 夏-91例 $(21.7 \%)$ 之春秋即ち季節の変り目に多い.

5）赤血球数, 血色素量, 色素指数, ヘマトクリッ 卜値, 白血球数, 好酸球数, リンパ球数については本疾 患上の相関々係認めない.

6) 出血傾向について: 血小板数, 出血時間 (Duke E法), 血液凝固時間 (Lee-White 氏変法) プロトロン ビン值（1 段法）についても相関関係は認められない。

7）肝機能及び 赤沈值について：総蛋白, A-G 比, 鿓揎指数, 硫酸覀鉛試験, 総 コレステロール值, BSP 試跧, 赤沈值について検索したが, 就中 A-G 比は正常 の下界を示すものが多く, 黄疾指数は約半数に高值を示 し, 赤沈值没約半数に軽度の穴進を認めた。他の諸検査 では殆ごが正常範囲を示した。
〔II〕䛦断及び治療の経過：血尿を主訴として訪机 た患者に対して, 尿検查 (混浊・䖝白・沈渣), 血液検查: （血色素量・色素指数・ヘマトクリット值・赤血球数・ 白血球数 - 好酸球数・リンパ球数 - 血小板数 - 出血時間! ・血液凝固時間・プロトロンビン值), Plasmin. 系及び Cholinesterase 系の測定の為の採血々採尿, 膀胱鏡検: 查, 血液化学検查 (尿素窒素・総蛋白・Na・K·Cl・ 7 才: スフアターゼ值), 肝機能検査 (黄疸指数・硫酸亜鉛試. 験・BSP 試験・総コレステロール値), レ線撮影 (腎部， 膀胱部単純撮影・静脈性腎孟撮影), トロンボェラストグ ラフ検查, 心電㘡検查ついで尿管カテーテル法学行い分 腎尿を採集した後に，必要あるものに対しては逆行性腎: 孟撮影を行つて診断を決定した. この間の諸検查で他疾 患梳鑑別されるのであるが治療期間中にも上記諸検查を 必要に応じて行い，他疾患の混入排除に努めた。 上記 Plasmin 系及び Cholinesterase 系の測定開始後諸検: 查終了までの約 1 週間ないし 2 週間の期間に一般的止血. 剂を約 1 週間投与しつ>日常生活を行わせ，その効果の ないととを確めた。（大部分の患者は既に来院前に一般

図 1 特発性腎出血（治療前）

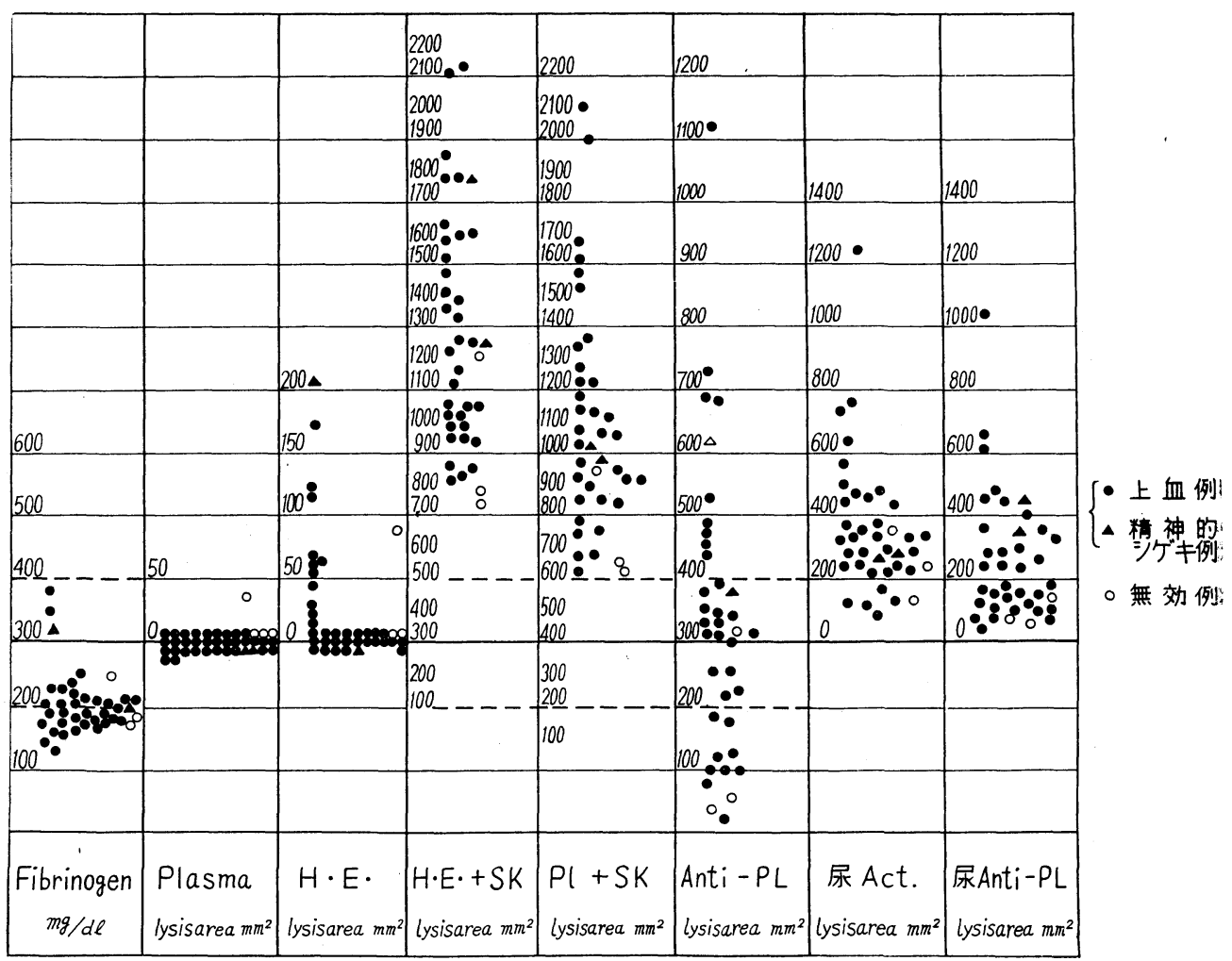


図 2 特発性腎出血（治療後）

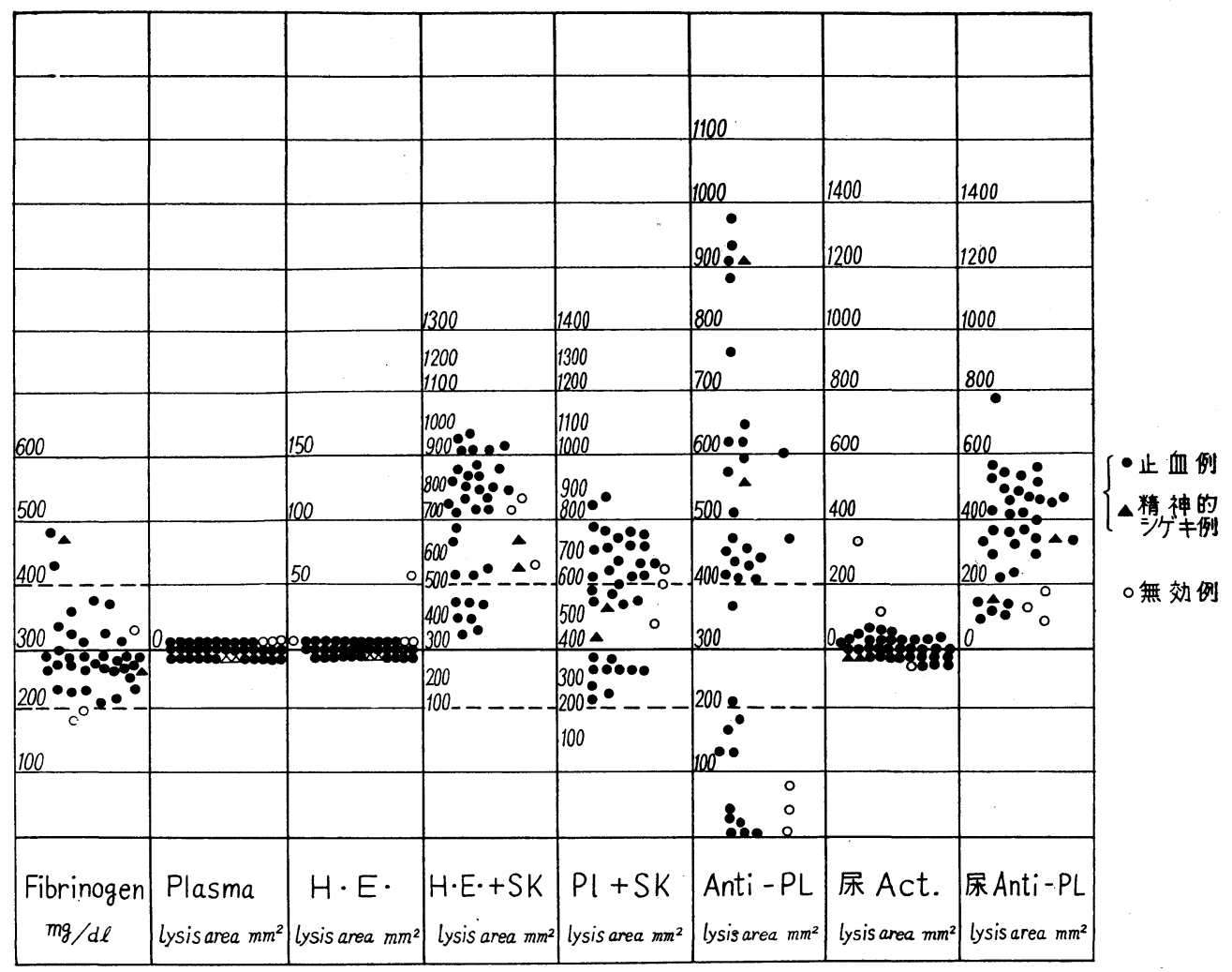

的止血剂をかなり長期間投与されて效果のみられなかつ たものである.）とれらの患者に対して外来的には 1 週 間々隔を以て測定を行いつ〉Antiplasmin 剂投与, 又 は Anticholinergic treatment を行い治療効果を認め たもので，投薬を中止して顕微鏡的に血尿の消失が 1 週 間持続したものを一応の治癒と見做し, 必要に応じて中 間測定をも行つた。

〔II] 線維素溶解酵素系について：(図1,図 2）

1）测定方法：著者等 ${ }^{67)}$ が既に発表したフイブリン平 板測定法に従つた。

2）患者数己投薬方法：40例の本疾患患者の治療前線 溶系各因子を測定した. 中 1 例は他病院に於て腎剔除術 を施行されたもので術後の測定が行われていない. 39例 中36例は治療により完全止血をみ，3 例は止血せず目下 検討中であり共に治療後の測定が行われた。投薬方法と しては antiplasmin 剤として (ย-ACA と略記) を $6 \mathrm{~g}$ ないし12 $\mathrm{g}$ を 1 日量として 4 回に分服せしめて 7 日ないし 35 日間投与した. 又 2 例は 精神的刺㦸による腎出血例で治療により止血した。 4 例
は経口投与で止血しないので更に直接腎盖内に高濃度 (60\%) $\varepsilon$-ACA を逆行的に注入して 3 例は止血し, 1 例は未止血例である。

3）治療前後に於ける各線溶系因子の比較（表 1)

(a) 線維素原量：治療前の本值は39例中約半数の15 例が正常値 ( 200 ない $400 \mathrm{mg} / \mathrm{dl}$ ) 以下であり, その平 均值は $208 \pm 13 \mathrm{mg} / \mathrm{dl}$. 治療後注未止血例の 2 例学除き全 例正常值以上となり，その平均值は $292 \pm 57 \mathrm{mg} / \mathrm{dl} .5 \%$ 危険率で有意の差を認める. 即ち治療により上昇するも のであり完全止血例の治療前平均值は $297 \pm 28 \mathrm{mg} / \mathrm{dl}$, 治 療後平均值は $208 \pm 17 \mathrm{mg} / \mathrm{dl} て ゙$ 同じく有意の差学認めるの であるが, 未止血例では治療前平均值は $206 \pm 97 \mathrm{mg} / \mathrm{dl}$. 治療後平均值は $233 \pm 189 \mathrm{mg} / \mathrm{dl}$ で有意の差を認めない.

（b）血漿の溶解面積: 治療前值は 1 例(完全止血例) の38 $\mathrm{mm}^{2}$ を除き全例 $0 \mathrm{~mm}^{2}$ であり, 治療後は全例 0 $\mathrm{mm}^{2}$ である.

(c) Euglobulin の溶解面積: 13例の異常九進值 $(17 \cdot 25 \cdot 30 \cdot 45 \cdot 56 \cdot 60 \cdot 64 \cdot 65 \cdot 81 \cdot 115 \cdot 120 \cdot$ 
表 1 の， 1

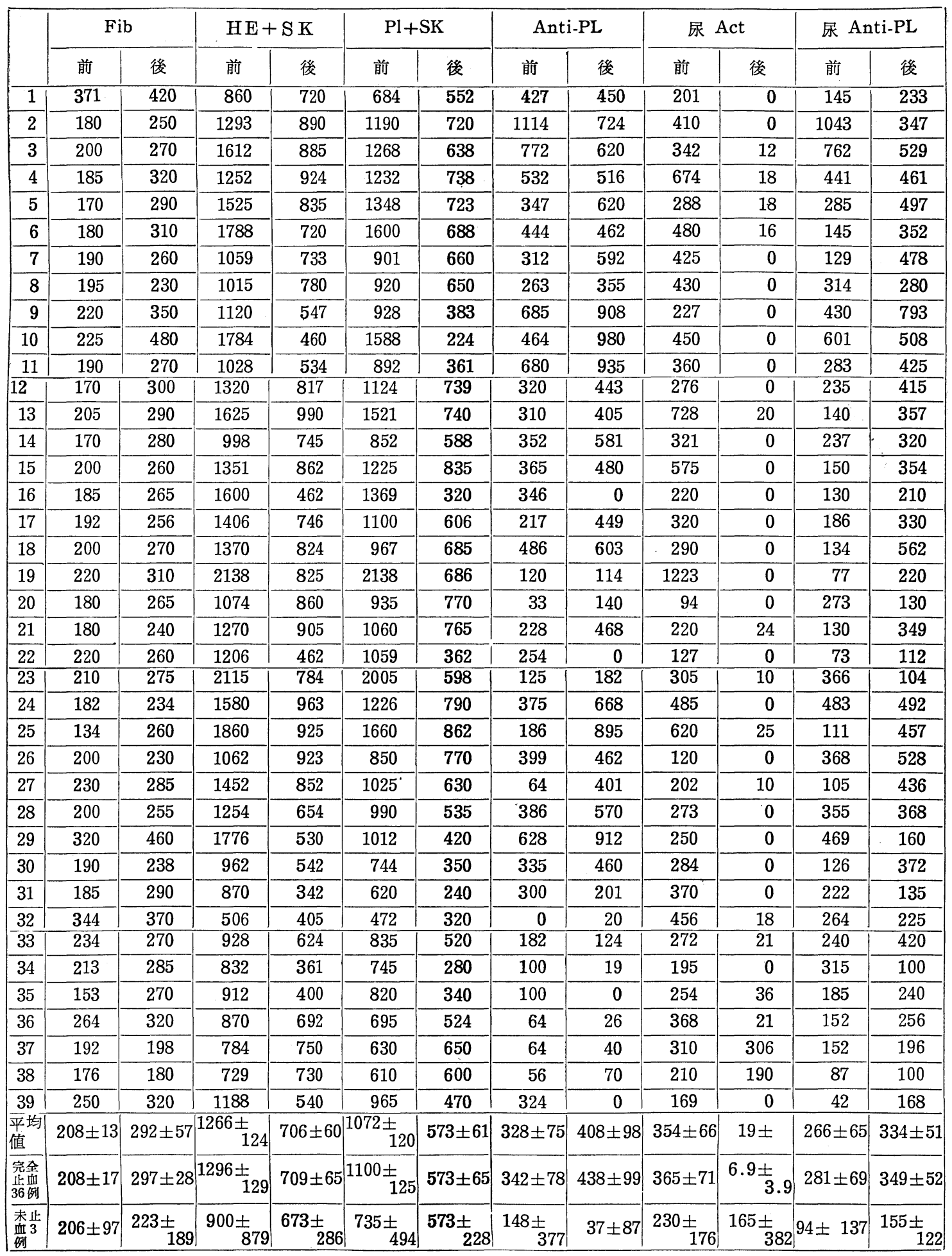


表 1 の $2 \varepsilon-\mathrm{ACA}$ 治療前後の検査所見（39例平均 值)

\begin{tabular}{|c|c|c|c|}
\hline \multirow[b]{2}{*}{ 血 } & Fib & 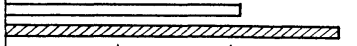 & 400 \\
\hline & $H \cdot E \cdot+S K$ & 202020102010 & 1500 \\
\hline 中 & $P L+S K$ & 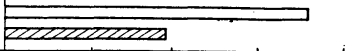 & 1500 \\
\hline & Anti-PL & 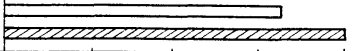 & 500 \\
\hline \multirow{2}{*}{$\begin{array}{l}\text { 尿 } \\
\text { 中 }\end{array}$} & Act & $\Longrightarrow$ & 500 \\
\hline & Anti-PL & 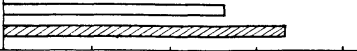 & 500 \\
\hline
\end{tabular}

口治療前曰治療後

169・207 $\mathrm{mm}^{2}$ ) を示す以外はすべて0 $\mathrm{mm}^{2}$ を現わ すのが治療前值であるが，乙の中未止血例は $81 \mathrm{~mm}^{2}$ と 他 2 例は $0 \mathrm{~mm}^{2}$ である. 治療後は未止血例の 1 例に60 $\mathrm{mm}^{2}$ をみる以外柱全例 $0 \mathrm{~mm}^{2}$ である.

（d） Euglobulin + Streptokinase の溶解面積: 本 值は全例に立進が認められ, 治療前平均値は1266士 124 $\mathrm{mm}^{2}$, 治療後平均值は $706 \pm 60 \mathrm{~mm}^{2}$ て $5 \%$ 危険率で 有意の差がみられ, 完全止血の36例の治療前平均値 1296 $\pm 129 \mathrm{~mm}^{2}$, 治療後平均值 $709 \pm 65 \mathrm{~mm}^{2}$. 未止血例の 治療前平均值 $900 \pm 879 \mathrm{~mm}^{2}$, 治療後平均值 $673 \pm 2$ $86 \mathrm{~mm}^{2}$ で両群とも治療前後の值に有意の差を認める.

（e）血漿+Streptokinase の溶解面積: 本値も全例 に六進が認められ, 治療前平均值 は1072土 $120 \mathrm{~mm}^{2}$, 治 療後平均值は $573 \pm 61 \mathrm{~mm}^{2}$ で有意の差を認める. 完全 止血例の治療前平均值は $1100 \pm 125 \mathrm{~mm}^{2}$, 治療後平均值 $573 \pm 65 \mathrm{~mm}^{2}$ で同じく有意の差を認めるが, 未止血例 の治療前平均值 $735 \pm 494 \mathrm{~mm}^{2}$, 治療後平均值 $573 \pm 2$ $28 \mathrm{~mm}^{2}$ で有意の差を認めない.

（f）抗 Plasmin 值：本疾患及者39例の治療前平均 值は $328 \pm 75 \mathrm{~mm}^{2}$, 治療後平均值は $408 \pm 98 \mathrm{~mm}^{2}$ で有 意の差を認める. 完全止血例 36 例の治療前平均值 $342 \pm$ $78 \mathrm{~mm}^{2}$, 治療後平均値 $438 \pm 99 \mathrm{~mm}^{2}$ と同じく有意の差を認 めるが, 未止血例治療前平均值 $148 \pm 377 \mathrm{~mm}^{2}$, 治療後 平均值 $37 \pm 87 \mathrm{~mm}^{2}$ と有意の差が認められない。

（g）尿中 activator 值：治療前の本值は一般的に 高值を示しその平均值は $354 \pm 66 \mathrm{~mm}^{2}$ であるが, 治療 により激減し特に完全止血例では大部分が $0 \mathrm{~mm}^{2}$ とな 门他のものはたかだか $50 \mathrm{~mm}^{2}$ までを示し, $10 \cdot 10 \cdot 12$ · $16 \cdot 18 \cdot 18 \cdot 18 \cdot 20 \cdot 21 \cdot 21 \cdot 24 \cdot 25 \cdot 36 \mathrm{~mm}^{2}$ と 13 例が $0 \mathrm{~mm}^{2}$ 以上の值定示し,未止血例は $306,190 \mathrm{~mm}^{2}$ と高い 2 例と $0 . \mathrm{mm}^{2}$ を示す 1 例をみるのである. 即ち 治療後平均值は $19 \pm 18 \mathrm{~mm}^{2}$ で前後に於て $5 \%$ 危険率で 有意の差が認められる. 又完全止血例 36 例の治療前平均
值 $365 \pm 7 / \mathrm{mm}^{2}$, 治療後平均值 $6.9 \pm 3.9 \mathrm{~mm}^{2}$, て有意 の差が認められる. 未止血例では治療により0又は0に 近くならない事であり 1 例の $0 \mathrm{~mm}^{2}$ を示すものは目下 他疾患の存在を究明中である.

（h）尿中抗 Plasmin 值: 治療前平均值は $266 \pm 65$ $\mathrm{mm}^{2}$, 治療後平均值心 $334 \pm 51 \mathrm{~mm}^{2}$ と有意の差がみら れ, 完全止血例の治療前平均值 $281 \pm 69 \mathrm{~mm}^{2}$, 治療後平 均值は $349 \pm 52 \mathrm{~mm}^{2}$, 又未止血例の治療前平均値 $94 \pm$ $137 \mathrm{~mm}^{2}$, 治療後平均值は $155 \pm 122 \mathrm{~mm}^{2}$ と両者とも 同じく前後に於て有意の差が認められる.

以上線溶系全体として $\varepsilon$-ACA による治療により改 善をみるのであるが特に止血例に於て尿中 activator が $0 \mathrm{~mm}^{2}$ 又はそれに近くなることが未止血例と対比して 特異的であり, 叉未止血例の 尿中 activator の高値の こと〉血中及び尿中抗 plasmin 值の比較的低值のとと は興味あることであり，1例の例外的な未止血例の症例 に対しては検討が行われている.

[IV]Cholinesterase 系 (ChE 系)について: 杉浦 ${ }^{58)}$ が既に発表したととろであるが要約すると次の如 くである゙:

1）正常人 21 例についてその血清中ChE值惊最高 27.0 $\mathrm{mg} / \mathrm{cc}$, 最低 $16.6 \mathrm{mg} / \mathrm{cc}$ 平均值 $22.65 \pm 1.56 \mathrm{mg} / \mathrm{cc}$ ある.

2）本疾患々者 39 例についてみるに, 最高 $22.7 \mathrm{mg} / \mathrm{cc}$, 最低 $10.0 \mathrm{mg} / \mathrm{cc}$ 平均值 $16.56 \pm 1.48 \mathrm{mg} / \mathrm{cc}$ 在示す. 即与正 常人に比して本疾患に者の 血清 $\mathrm{ChE}$ 值は低值を示して いるととが明かである。と〉で acetylcholine 抑制昘て ある硫酸 atropin こ ChE 活性風であるチ才硫酸ソー ダ併用による治療をと〉ろみた。硫酸 atropin 3.0mg 及びチ才硫酸 ソーダ (Hypon 錠) $4.9 \mathrm{~g}$ 学 1 日量とし て 4 回分服させ，7 日ないし14日間連続投与して39例中 22例に完全止血をみ, 17例が未止血例である. 完全止血 例 22 例の 投与前平均值 $16.07 \pm 2.01 \mathrm{mg} / \mathrm{cc}$, 投与後平均 值 $19.54 \pm 2.49 \mathrm{mg} / \mathrm{cc}$ こ $3.37 \pm 0.69 \mathrm{mg} / \mathrm{cc}$ の上昇をみるが 尚正常範囲を示すものは10例約半数であり, 残り12例は 正常值以下である.つぎに未止血例17例の投与前平均值 $17.07 \pm 2.04 \mathrm{mg} / \mathrm{cc}$, 投与後平均值 $17.65 \pm 2.30 \mathrm{mg} / \mathrm{cc}$ と 前後に於て有意の差が認められない.

[V】 線溶系と ChE 系の日内変動について：8例 について 6 時間ごとに採血採尿し, それぞれについて線 溶系各因子と $\mathrm{chE}$ 值を検索した. 各例とも日内変動を 認动, 第 1 例から第 7 例 (図 $3,4,5,6,7,8,9$, ) まで日中 に線溶能は比較的に低く, chE 值は比較的に高值を示 し, 夜間は反対に比較的に線溶能は高く, $\mathrm{ChE}$ 值は低 值を示す型を認めるが, 第 8 例 (図10) のみはこれらと 
図 3 鈴 $\bigcirc$ 重 今 21 左腎出血

$$
\begin{array}{llll}
12^{\circ} \quad 18^{\circ} \quad 24^{\circ} \quad 6^{\circ} \quad 12^{\circ} \\
\hline
\end{array}
$$

Fibrinogen $\mathrm{mg} / \mathrm{dl} 230 \quad 200 \quad 200 \quad 200 \quad 200$

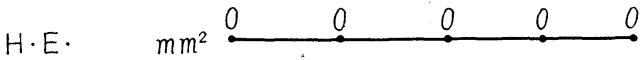

Plasma $\mathrm{mm}^{2} \stackrel{0}{0} \quad 0 \quad 0 \quad 0 \quad 0 \quad 0$

$H \cdot E \cdot+S K m^{2} \stackrel{1197 \quad 1267 \quad 1452 \quad 1366 \quad 1153}{1267}$

$\mathrm{Pl} .+\mathrm{SK} \quad \mathrm{mm}^{2} \stackrel{960 \quad 990 \quad 1025 \quad 988 \quad 960}{ }$

Anti-PL $\mathrm{mm}^{2} \stackrel{68 \quad 64 \quad 64 \quad 64 \quad 105}{6}$

尿 Act. $\mathrm{mm}^{2} \begin{array}{llllll}160 & 175 & 202 & 183 & 189\end{array}$

尿 Anti-PL mm $m^{2} \begin{array}{lllll}75 & 70 & 105 & 88 & 80\end{array}$

ChE $\quad \mathrm{mg} / \mathrm{cc}^{22.2} \quad 20.2 \quad 20.0 \quad 20.0 \cdot 22.1$

図 4 菊○賢 $\bigcirc 22$ 左腎出血

$$
\begin{array}{llll}
12^{\circ} \quad 18^{\circ} & 24^{\circ} & 6^{\circ} & 12^{\circ} \\
\hline
\end{array}
$$

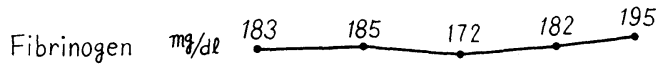
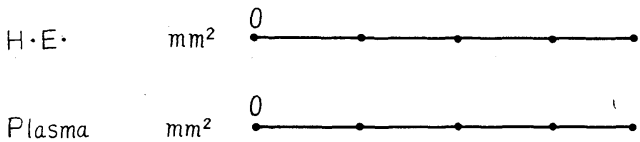

$H \cdot E+S K \quad m^{2} \quad 1180 \quad 1095 \quad 1260 \quad 1150 \quad 1196$

$\mathrm{Pl}+\mathrm{SK} \quad \mathrm{mm}^{2} \cdot$\begin{tabular}{lllll}
1325 & 1224 & $1560 \quad 1167 \quad 1208$ \\
\hline
\end{tabular}

Anti-PL $\mathrm{mm}^{2} \quad$\begin{tabular}{lllll}
$143 \quad 100 \quad 120$ & $121 \quad 110$ \\
\hline
\end{tabular}

层 Act.

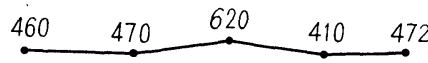

尿 Anti-PL

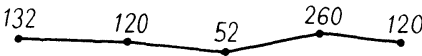

ChE $\quad \mathrm{mg} / \mathrm{cc}$

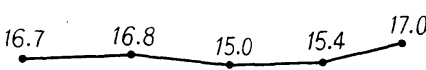

図 5 銭 $\bigcirc$ 則 $\bigcirc 22$ 腎出血（部位不明）

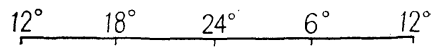

Fibrinogen $\mathrm{mg} / \mathrm{dl} \quad \begin{array}{lllll}300 & 300 & 300 \quad 320 \quad 310\end{array}$

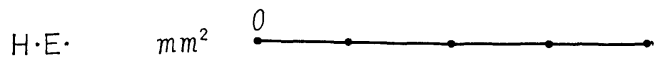

Plasma $\mathrm{mm}^{2}$

$H \cdot E \cdot+S K \quad m^{2}$

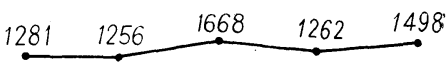

$\mathrm{PI}+\mathrm{SK} \quad \mathrm{mm}^{2}$

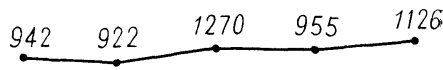

Anti-PL $\mathrm{mm}^{2}$

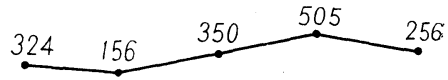

尿 Act.

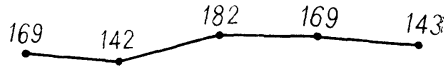

尿 Anti-PL

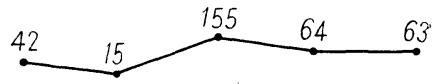

Ch E. $\quad m g / c c$

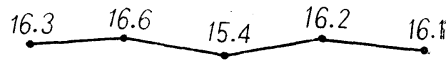

圀 6 高 $\bigcirc$ 正 $\bigcirc 46$ 左腎出血
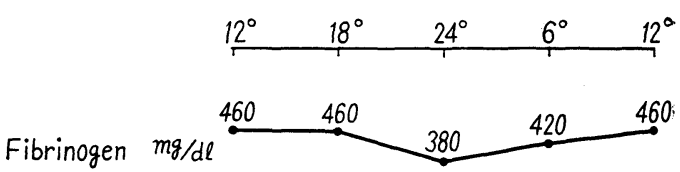

$\mathrm{H} \cdot \mathrm{E} \quad \mathrm{mm}^{2}$

Plasma $\mathrm{mm}^{2}$

$H \cdot E+S K m^{2} 850$

$\mathrm{Pl}+\mathrm{SK} \quad \mathrm{mm}^{2} \quad \begin{array}{lllll}730 \quad 730 \quad 905 \quad 810 \quad 750 & \end{array}$

Anti-PL $\mathrm{mm}^{2} \begin{array}{lllll}121 & 100 \quad 105 & 108 & 110\end{array}$

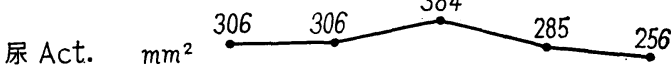

尿 Anti-PL mm $\begin{array}{llllll}205 & 205 & 220 \quad 250 \quad 256 & \end{array}$

ChE $\mathrm{mg} / \mathrm{cc}$ 
図7 林○

\begin{tabular}{lllll}
$12^{\circ} \quad 18^{\circ}$ & $24^{\circ}$ & $6^{\circ}$ & $12^{\circ}$ \\
\hline
\end{tabular}

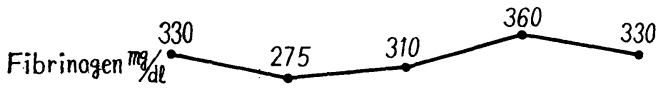

$\mathrm{H} \cdot \mathrm{E} \quad \mathrm{mm}^{2} \stackrel{\mathrm{O}}{\longrightarrow}$
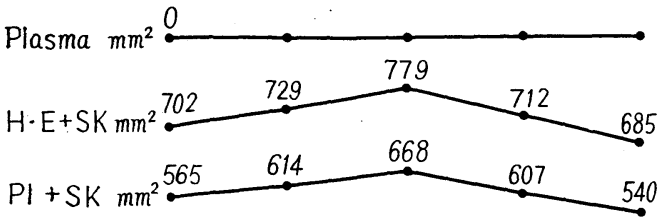

Anti-PL mm $m^{2} 38 \quad 115 \quad 121 \quad 110 \quad 155$

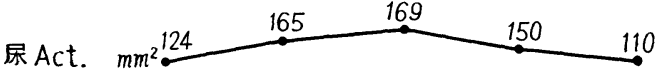

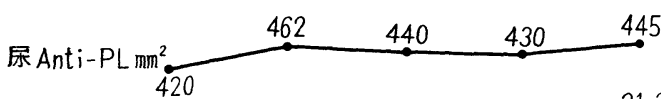

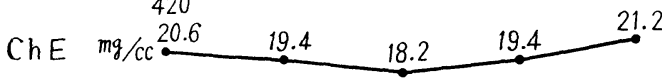

図8 佐○間○ 223 左腎出血

\begin{tabular}{lllll}
$12^{\circ} \quad 18^{\circ} \quad 24^{\circ} \quad 6^{\circ} \quad 12^{\circ}$ \\
\hline
\end{tabular}

Fibrinogen $\mathrm{mg} / \mathrm{dl} \quad \stackrel{530 \quad 506 \quad 506 \quad 530 \quad 522}{\longrightarrow}$

$\mathrm{H} \cdot \mathrm{E} \quad \mathrm{mm}^{2} \stackrel{\mathrm{O}}{\longrightarrow}$

Plasma $\mathrm{mm}^{2} \stackrel{\mathrm{O}}{\longrightarrow}$

$\mathrm{H} \cdot \mathrm{E}+\mathrm{SK} \quad \mathrm{mm}^{2}$\begin{tabular}{lllll}
$574 \quad 587$ & 784 & 613 & 580 \\
\hline
\end{tabular}

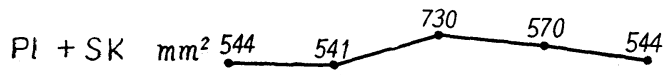

Anti - PL mm m $\begin{array}{lllll}30 \quad 53 & 46 \quad 48 & 48\end{array}$

杘 Act. $\mathrm{mm}^{2} 301 \quad 306 \quad 324 \quad 248 \quad 315$

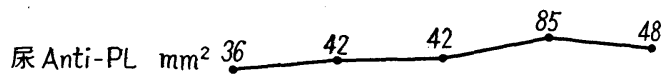

ChE $\quad m g / c c$

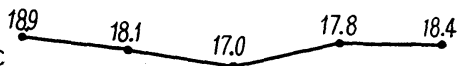

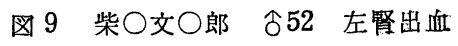

Fibrinogen

\begin{tabular}{rrrrr}
$12^{\circ} \quad 18^{\circ} \quad 24^{\circ} \quad 6^{\circ}$ & $12^{\circ}$ \\
\hline
\end{tabular}

$\mathrm{H} \cdot \mathrm{E} \cdot \quad \mathrm{mm}^{2} \mathrm{O}$

Plasma $\quad m m^{2}$

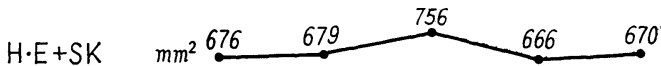

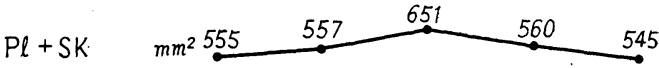

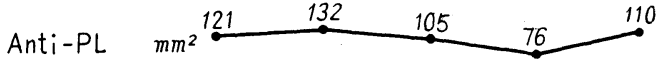

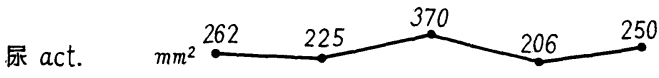

杘 anti-PL mm $\begin{array}{lllll}381 & 353 & 360 & 361 & 365\end{array}$

ChE

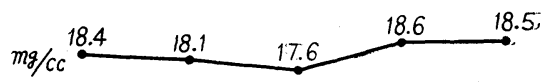

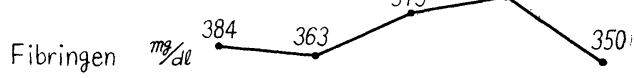

$\mathrm{H} \cdot \mathrm{E} \quad \mathrm{mm}^{2}$

Plasma $\quad \mathrm{mm}^{2}$ ?

$H \cdot E+S K \quad m m^{2} \stackrel{1592 \quad 1554 \quad 1217 \quad 1175 \quad 1600}{ }$

$\mathrm{Pl}+\mathrm{SK} \quad \mathrm{mm}^{2}$

Anti-PL $\quad m^{2}{ }^{121} \quad \begin{array}{lllll}144 & 160 \quad 160 & 164\end{array}$

尿Act.

$\mathrm{mm}^{2} \stackrel{480 \quad 444 \quad 400 \quad 353 \quad 494}{\stackrel{4}{4}}$

尿Anti-PL mm ${ }^{2} \stackrel{100 \quad 120 \quad 130 \quad 256}{2} 78$

ChE

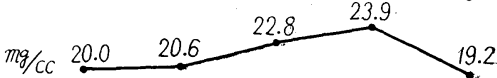


四11 小○山 우 57 左腎出血

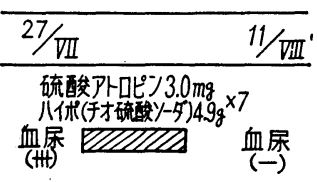

Fig

$m g / d p$

134

0

$P$

$H \cdot E$

$H \cdot E+S K$

$\mathrm{PI}+\mathrm{SK}$

Anti-PL $\quad \mathrm{m}^{2}$

㧰 Act.

搌 Anti - PL

$C h \div E$

$m m^{2}$

$m m^{2}$

25

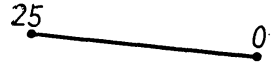

$m m^{2}$

$m m^{2}$

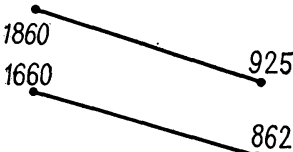

186

$\cdot m m^{2}$

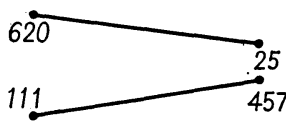

$m m^{2}$ $m g / c c$

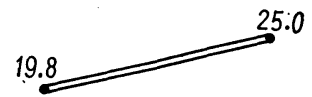

図12 羽○ 仓 41 右腎出血

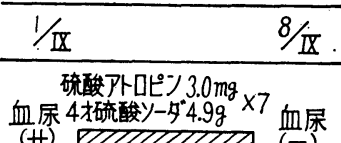

Fig

PI

$H \cdot E$

$H \cdot E+S K$

$\mathrm{Pl}+\mathrm{SK}$

Anti-PL $\quad \mathrm{m}^{2}$

层Act. $\mathrm{mm}^{2}$

层Anti-PL $\mathrm{mm}^{2}$

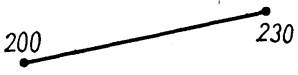

$\mathrm{mm}^{2}$

$m m^{2}$
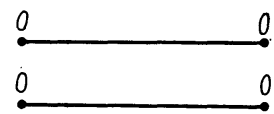

1062
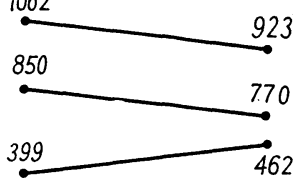

120
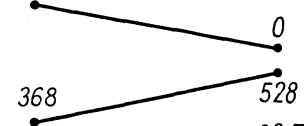

26.7

.Ch - E

$\mathrm{mg} / \mathrm{cc}$

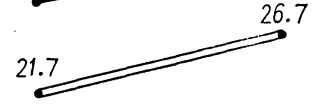

Fig

$\mathrm{Pl}$

$H \cdot E$

$\mathrm{H} \cdot \mathrm{E}+\mathrm{SK} \quad \mathrm{mm}^{2}$

$\mathrm{Pl}+\mathrm{SK} \quad \mathrm{mm}^{2}$

Anti-PL $\mathrm{mm}^{2}$

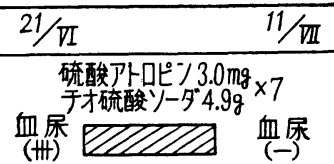

182

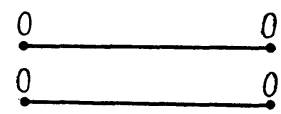

1580
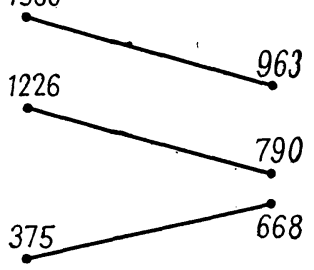

尿 Act. $\mathrm{mm}^{2}$

尿 Anti-PL $\mathrm{mm}^{2}$

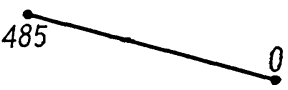

483

492

Ch-E

$m g / c c$

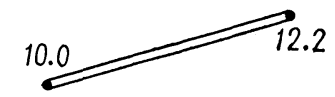


図14 森○우 29 腎出血（部位不明）
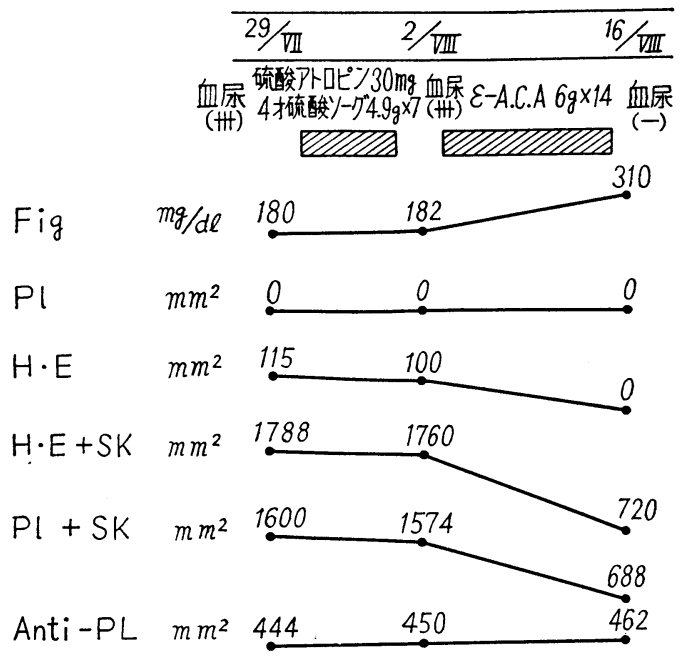

层Act. $\mathrm{mm}^{2}$

尿Anti-PL $\mathrm{mm}^{2}$

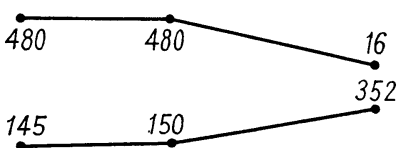

$\mathrm{Ch}-\mathrm{E} \quad \mathrm{mg} / \mathrm{cc}$

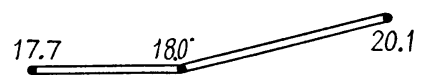

（図15）は34才男子の左腎出血で図に示す如く初診時高 度の血尿を来し, 線溶系各因子も六僬を示している。

$\boldsymbol{E}-\mathrm{ACA}$ を 1 日量 $5 \mathrm{~g}$ 経口的に21日間投与し(計 $105 \mathrm{~g}$ ), 血尿は鏡検で士（ 400 倍， 1 視野に 0 ないし 1 ケの赤血
球)の程度で線溶系各因子は著しく改善を示し, 尿中 activator も激減したが $0 \mathrm{~mm}^{2}$ をはならなかつたので投 与量を $6 \mathrm{~g}$ k増加して更に 1 週間補足すると尿中 acti vator は $0 \mathrm{~mm}^{2}$ となり鏡検的にも完全止血を示した。 第 2 例(図16)は64才男子左㹂出血で初診時高度の血尿を 認め, 線溶系各因子も著しい光進を示している。 を 1 日量 $6 \mathrm{~g}$ を 7 日間投与したが血尿の程度に変化は. 認められず，乙の時の線溶系各因子の測定はフイブリ゙ ン平板の不良から求められなかつた。 そこで投与量を 12 $\mathrm{g}$ に倍量して 7 日間投与後には血尿の程度は軽減し線溶 系各因子も軽度の改善をみて, 尿中 activator は 107. $\mathrm{mm}^{2}$ と尚六進が認められる. その後 3 週間投与が継続 され総計 $\varepsilon-\mathrm{ACA}$ が $378 \mathrm{~g}$ 投与された時に完全止血をみ心 て線溶系各因子も著しく改善され尿中 activator も低 下して18 $\mathrm{mm}^{2}$ を示すに至つた. 第 3 例 (図17) は 32 才 男子で顕微鏡的に血尿はかなり高度であるが，膀脱鏡的; にはその出血部位を確認することができず又膀胱内系に は全く異常が認められない例である。初診時線溶系各因 子はかなり充進しており，ع-ACA を 1 日量 $6 \mathrm{~g}, 7$ 日 間投与すると止血が確認され線溶系各因子も改善され， 尿中 activator は $0 \mathrm{~mm}^{2}$ を示した。投薬を中止して 14日間放置しておくと再び血尿を来し, 線溶系も妄進し 尿中 activator も rebound して $205 \mathrm{~mm}^{2}$ を示した。 そこで再び $\varepsilon$-ACA を $12 \mathrm{~g}$ に倍量して 29 日間投与すると 線溶系は著しい改善を示し, 特に尿中 activator は0 $\mathrm{mm}^{2}$ となり，その後再出血をみない。第 4 例 (図18)

図15 高○喜○ 034 左堅出血

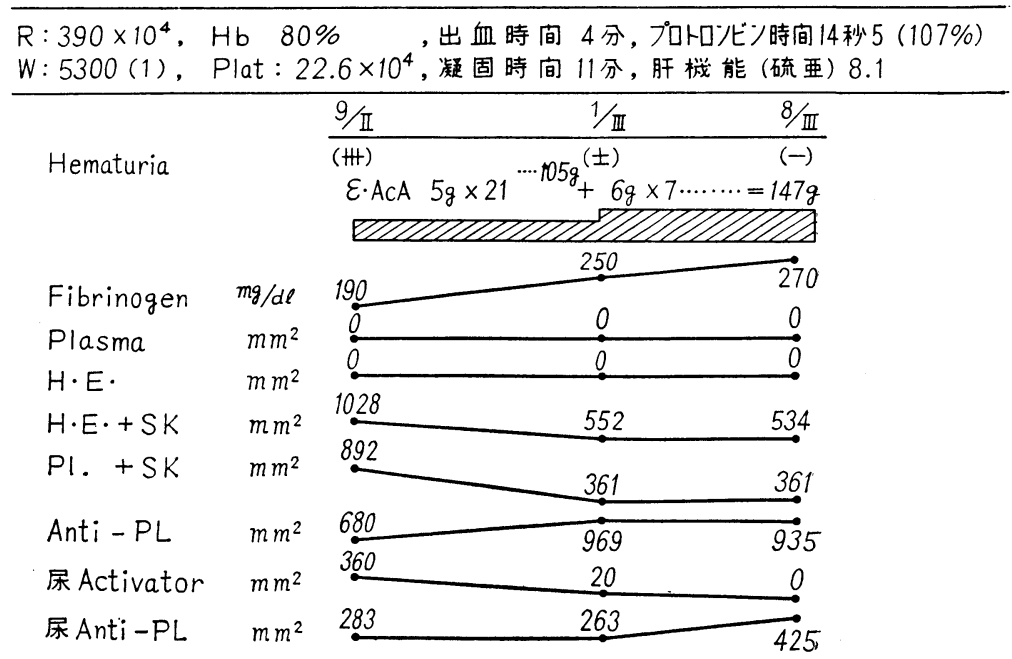


図16 沢○佐○治 占64 左腎出血

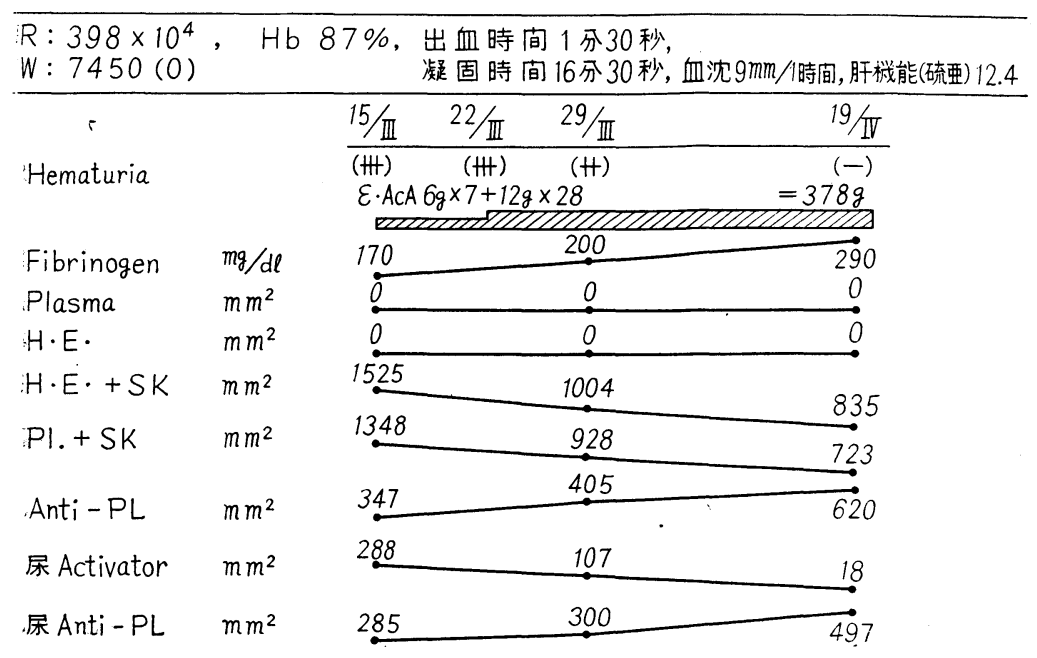

図17 松○敬 $\bigcirc 32$ 堅出血（部位不明：膀腅内正常）

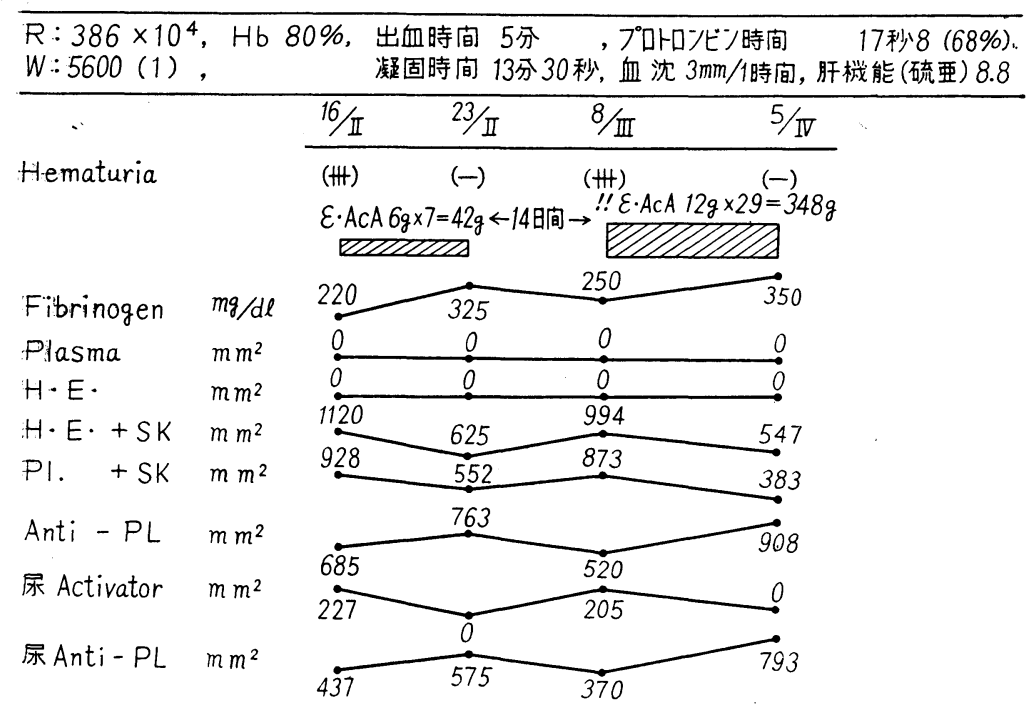

は38才男子左腎出血．初診時高度の血尿を示し線溶系も 著しい充進を認めた。 $\boldsymbol{\varepsilon}$-ACA を 1 日量 $6 \mathrm{~g}$ 経口的に14 日間投与すると血尿の程度は著しく減少した。 との時の 線溶系各因子の測定は成功しなかつたが，投与量を12 gに倍量して 21 日間投与を続行すると血尿は認められ ず, 線溶系もかなりの改善が認められた。 こ〉で投薬 を中止して 30 日間放置すると再び血尿を来し線溶系各因 子もかなりの充進を示し rebound が認められた。 そこ で抗アレルギー剂を約 30 日間投与したが止血効果は認め
られず, 線溶系も前回の測定值と大差が認められず，む しろ軽度の元進を示した. 再び $\boldsymbol{\varepsilon}$-ACA 1 日量 $12 \mathrm{~g} て ゙$ 28 日間計 $336 \mathrm{~g}$ 投与すると止血効果安認的, 線溶系注改 善されたが，尿中 activator ので, 更に 7 日間投与が追加された。 即ち $\varepsilon$-ACA 総計 $420 \mathrm{~g}$ 投与時の線溶系は前回と余り差が認められないが 尿中 activator は18 $\mathrm{mm}^{2}$ を示した。 こ〉で投薬を中 止したが再出血を認めなかつた。第 5 例（図19）は34才 女子游走腎を伴う左腎出血例である. 初診時かなりの血 
図18 川○仁○衛○令38 左腎出血

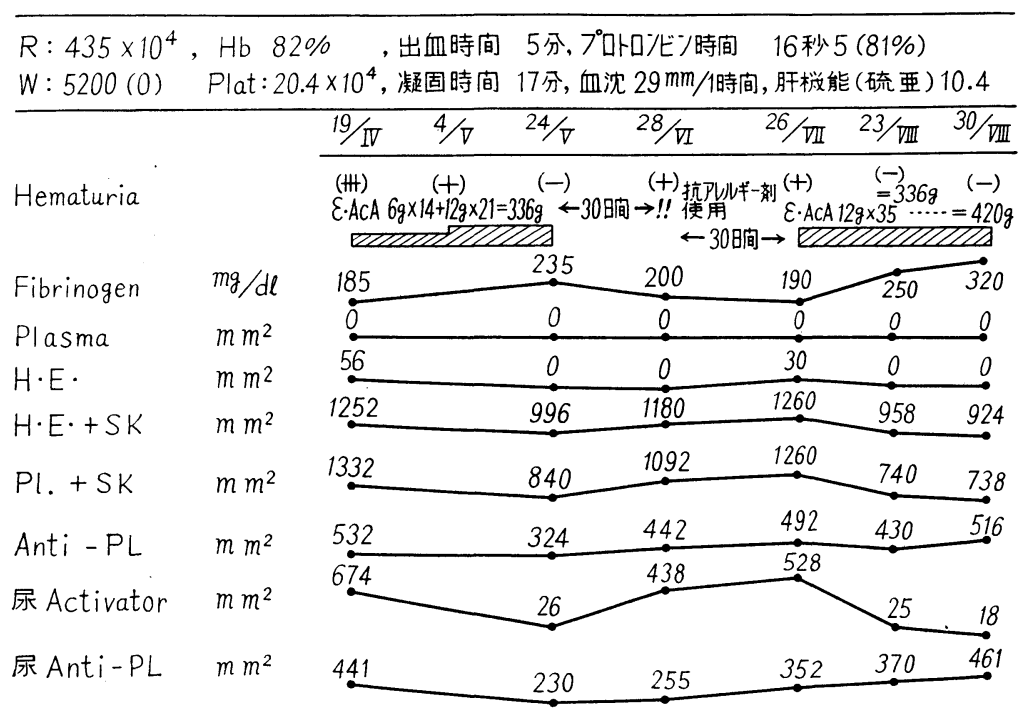

図19 吉 $\bigcirc$ 和 $\bigcirc$ 우 34 左腎出血（游走腎）

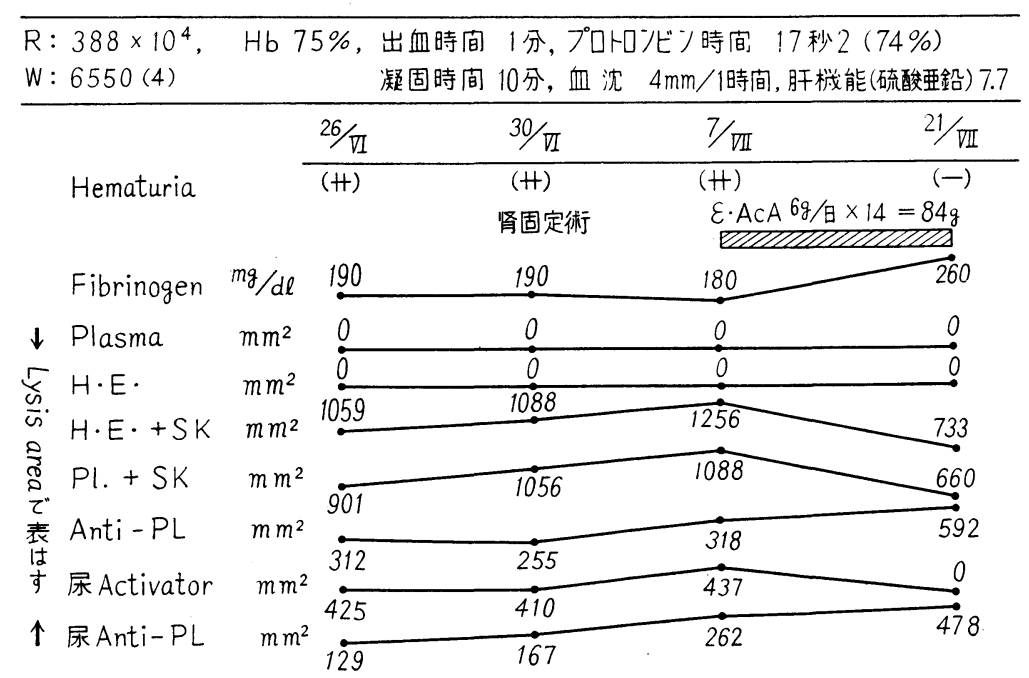

漮と線溶系の光進を示してい心. 4 日後に腎固定術が行 われたが血尿は変らず線溶系各因子も不変の状態であ り, その後 7 日を経過した時に於ても血尿ばつぶき, 線 溶系はむしろ軽度の元進がみられた。 そこで $6-\mathrm{ACA} 1$ 日量 $6 \mathrm{~g}$ が14日間投与されると止血効果が確認され線溶 系も著しく改善され就中尿中 activator $120 \mathrm{~mm}^{2}$ を 示した. 第 6 例（図20）は22才男子右腎出血で初診時の 線溶系法著しい圥進を示し $\varepsilon$-ACA 1 日量 $6 \mathrm{~g}$ が30日間
に亘つて投与されたが, 血尿の程度も変らず線溶系も改 善を示さない. そこで投与を中止して他の一般的止血戍 を 3 週間投与したが血尿線溶系ともに著変をみない. 尿 管カテーテル法を行い腎孟に生理的食塩水を注入し $8 \mathrm{cc}$ で压迫感を訴えたので中止し, その後 anticholinergic treatment を図の如く7 日間行つたが著変を認めない. 再び尿管カテーテル法を行い, $60 \% \varepsilon-\mathrm{ACA}$ を腎孟内に $10 \mathrm{cc}$ 注入した。痛及を訴え最高 $39^{\circ} \mathrm{C}$ 亿及゙発熱をみて 


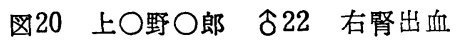

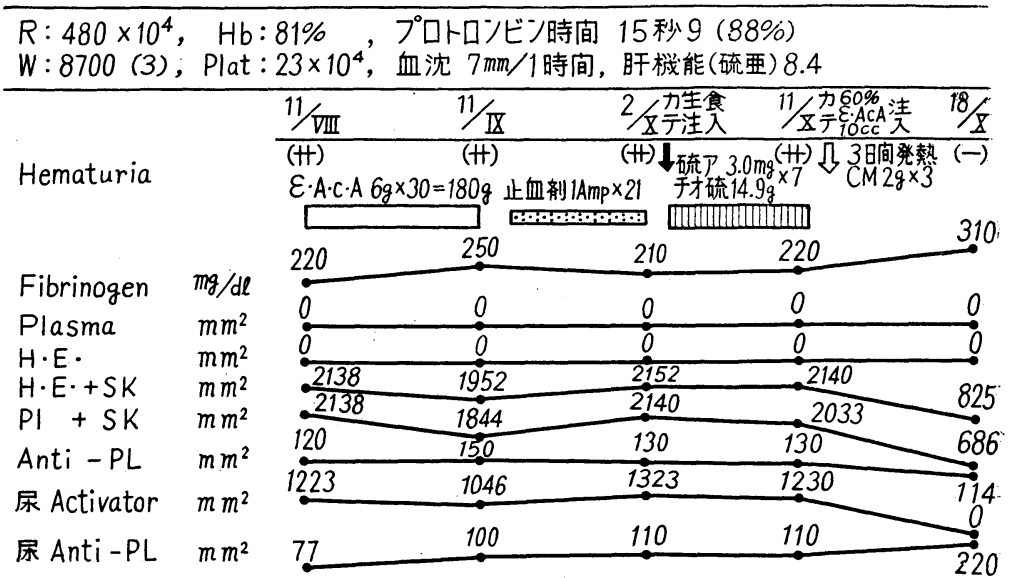

表 2 腎動脈, 腎静脈上り同時採血標本について 線䧽素溶解酵素系, Cholinesterase 系の測定值（手術時）

\begin{tabular}{|c|c|c|c|c|c|c|c|c|}
\hline 番号 & 氏 & 名 & 性 & 年令 & 診 断 & 測 定 項 目 & 動脈血測定值 & 静脈血測定值 \\
\hline \multirow{4}{*}{1} & \multirow{4}{*}{ 笹 } & \multirow{4}{*}{0} & \multirow{4}{*}{ § } & \multirow{4}{*}{67} & \multirow{4}{*}{$\begin{array}{l}\text { 左尿管腫 } \\
\text { 機能 }+ \text { ) }\end{array}$} & $\mathrm{H} \cdot \mathrm{E}$ & 0 & 0 \\
\hline & & & & & & $\mathrm{HK}+\mathrm{SK}$ & 1292 & 1410 \\
\hline & & & & & & anti-PL & 232 & 124 \\
\hline & & & & & & ChE $\mathrm{mg} / \mathrm{cc}$ & 11.6 & 8.6. \\
\hline \multirow{4}{*}{2} & \multirow{4}{*}{ 柏 } & \multirow{4}{*}{ O } & \multirow{4}{*}{$\hat{o}$} & \multirow{4}{*}{27} & \multirow{4}{*}{$\begin{array}{l}\text { 右水腎症 } \\
(\text { 機能 }+ \text { ) }\end{array}$} & $\mathrm{H} \cdot \mathrm{E}$ & 0 & 0. \\
\hline & & & & & & $\mathrm{HE}+\mathrm{SK}$ & 625 & 884 \\
\hline & & & & & & anti-PL & 99 & 64 \\
\hline & & & & & & ChE $\mathrm{mg} / \mathrm{cc}$ & 12.6 & 10.0 \\
\hline \multirow{4}{*}{3} & \multirow{4}{*}{ 紊 } & \multirow{4}{*}{0} & \multirow{4}{*}{ 우 } & \multirow{4}{*}{40} & \multirow{4}{*}{$\begin{array}{c}\text { 右腎結核 } \\
(\text { 機能+) }\end{array}$} & $\mathrm{H} \cdot \mathrm{E}$ & 0 & 0 \\
\hline & & & & & & $\mathrm{HE}+\mathrm{SK}$ & 625 & 800 \\
\hline & & & & & & anti-PL & 144 & 84 \\
\hline & & & & & & $\mathrm{ChE} \quad \mathrm{mg} / \mathrm{cc}$ & 18.6 & 14.8 \\
\hline \multirow{4}{*}{4} & \multirow{4}{*}{ 会 } & \multirow{4}{*}{$\bigcirc$} & \multirow{4}{*}{ 우 } & \multirow{4}{*}{39} & \multirow{4}{*}{$\begin{array}{c}\text { 左腎結核 } \\
\text { (機能一) }\end{array}$} & $\mathrm{H} \cdot \mathrm{E}$ & 0 & 0. \\
\hline & & & & & & $\mathrm{HE}+\mathrm{S} \mathrm{K}$ & 790 & 805 \\
\hline & & & & & & \begin{tabular}{c|c}
$\mathrm{mm}^{2}$ & anti-PL \\
\end{tabular} & 85 & 73 \\
\hline & & & & & & ChE $\mathrm{mg} / \mathrm{cc}$ & 13.3 & 13.3 \\
\hline & & & & & & \begin{tabular}{l|l} 
線 & $\mathrm{H} \cdot \mathrm{E}$ \\
\end{tabular} & 0 & 0 \\
\hline & & & & & 右腎孟腎 & $\mathrm{HE}+\mathrm{SK}$ & 588 & 644 \\
\hline 5 & 鈴 & O & 우 & 52 & （尿管逆 & $\begin{array}{ll} & \text { m } \\
\mathrm{mm}^{2} & \text { anti-PL }\end{array}$ & 120 & 66 \\
\hline & & & & & 流） & ChE $\mathrm{mg} / \mathrm{cc}$ & 18.7 & 15.4 \\
\hline & & & & & & $\mathrm{H} \cdot \mathrm{E}$ & 0 & 0. \\
\hline & & & & & 腎孟腎炎 & $\mathrm{HE}+\mathrm{SK}$ & 388 & 548 \\
\hline 6 & 田 & 0 & 우 & 21 & (尿管逆 & \begin{tabular}{c|c}
$\mathrm{mm}^{2}$ & anti-PL \\
\end{tabular} & 16 & 9 \\
\hline & & & & & & ChE mg/cc & 19.5 & 16.2 \\
\hline & & & & & & $\mathrm{H} \cdot \mathrm{E}$ & 0 & 68 \\
\hline & & & 잉 & 27 & & 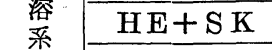 & 741 & 1050 \\
\hline 7 & 佐 & 0 & $\vec{T}$ & 21 & 餐出血 & $\begin{array}{lll}\mathrm{mm}^{2} & \text { anti-PL } \\
\end{array}$ & 100 & 64. \\
\hline & & & & & & ChE $\quad \mathrm{mg} / \mathrm{cc}$ & 19.4 & 15.2 \\
\hline
\end{tabular}


3 日間臥床，抗生物質の投与で下熱し注入後 5 日で尿 は透明こなり，7 日後に注全く止血効果がみられ線溶系 も改善され，就中尿中 activator は $0 \mathrm{~mm}^{2}$ を示して Wる. 尚 4 例にこの様な逆行的に直接腎醞内に $60 \% \varepsilon$-ACA を $3 \mathrm{cc}$ なし，10cc注入を行つたが，この第6 例以 外にも 1 例の止血效果をみたものと, 1 例 8 日後に軽い 血尿をみて $\varepsilon$-ACA 1 日量12 g 学12日間計 $150 \mathrm{~g}$ を追加 経口投与して完全止血をみた例があり，残りの 1 例恰 討例として後に述べるが尿中 activator が0 $\mathrm{mm}^{2}$ を 示しながら未止血例として考えられるものである. 注入 後止血効果をみたものの排泄性腎孟撮影像も正常であり 注入による障碍はないものと考えられる。

〔VIII〕腎局在性 activator について（手術時腎動静 脈より同時採血した標本についての線溶系及び ChE 值 について）（表 $2 ）$ : 表に示す如く尿管腫瘍 1 例・水腎 症 1 例・腎結核 2 例・尿管逆流子伴了腎㙉腎炎 2 例・特 発性腎出血 1 例の計 7 例について検索が行われた. 即ち 動脈血の方が静脈血よりも総 plasmin 值 仗低值であ り, 抗 plasmin 值及び ChE 值は高值を示している. 症例 4 の機能の殆ど認められなかつた腎結核に於ては両 者の間に差が認められない. 又症例 7 のだ1例の手術 の機会を得た本疾患例では他と同様に静脈血の方が強い 線溶能を示し ChE 值は低いのであるが Euglobulin fraction のみでも 線溶の起つているととは興味ある点で

表 3 正常人における尿中 activator 及び anti-Plasmin

\begin{tabular}{|c|c|c|c|c|c|c|}
\hline 番号 & 氏 & 名 & 性 & 年令 & $\mid$ 尿 activator & $\begin{array}{l}\text { 尿 anti- } \\
\text { Plasmin }\end{array}$ \\
\hline 1 & 檈 & 0 & $\hat{0}$ & 26 & 18 & 240 \\
\hline 2 & 上 & 0 & $\hat{\delta}$ & 27 & 16 & 196 \\
\hline 3 & 岡 & 0 & $\hat{0}$ & 27 & 25 & 324 \\
\hline 4 & 星 & 0 & $\hat{0}$ & 27 & 20 & 182 \\
\hline 5 & 北 & 0 & $\hat{0}$ & 35 & 16 & 240 \\
\hline 6 & 岩 & 0 & $\hat{0}$ & 28 & 20 & 240 \\
\hline 7 & 寺 & 0 & $\hat{0}$ & 29 & 16 & 252 \\
\hline 8 & 中 & 0 & $\hat{\delta}$ & 29 & 20 & 240 \\
\hline 9 & 郷 & 0 & $\hat{0}$ & 29 & 25 & 272 \\
\hline 10 & 木 & 0 & $\hat{\delta}$ & 30 & 18 & 156 \\
\hline 11 & 広 & 0 & $\hat{0}$ & 29 & 18 & 225 \\
\hline 12 & 小 & 0 & $\widehat{\delta}$ & 29 & 36 & 225 \\
\hline 13 & 杉 & 0 & $\hat{0}$ & 30 & 16 & 210 \\
\hline 14 & 阿 & 0 & $\hat{\delta}$ & 30 & 25 & 296 \\
\hline 15 & 米 & 0 & $\hat{0}$ & 36 & 64 & 324 \\
\hline 計 & 平 & 均 & & & $\begin{array}{r}353 \\
23.5 \\
\end{array}$ & $\begin{array}{r}3622 \\
241.4 \\
\end{array}$ \\
\hline
\end{tabular}

ある.

[IX]尿中 activator について

1）正常人尿中 activator について（表 3 ）：表に 示す如く15名の正常人の尿中 activator は極めて低值 であり，０ $\mathrm{nm}^{2}$ を示すものはなかつたがおよそ 100 $\mathrm{mm}^{2}$ 以下であり, その平均は $23.5 \mathrm{~mm}^{2}$ である. 一方 尿中抗 plasmin 値も $100 \mathrm{~mm}^{2}$ から $400 \mathrm{~mm}^{2}$ の間に ありその平均は $241.4 \mathrm{~mm}^{2}$ てあり本疾患々者のそれと 大差がみられない.

2）特発性腎出血患者の分腎尿 activator について （表 4）：表に示す様に11例の本疾患々者の分腎尿を採 集してその尿中 activator 比較し中 2 例は治療の経 過中にもその変動を観察した. 即ち未処置の本疾患々者 に於ては患側腎尿に activator が高值であることが明 かである. 症例10は血尿の程度が $\varepsilon$-ACA 1 日量 $6 \mathrm{~g} て ゙$ 2 週間計 $84 \mathrm{~g}$ でかなり改善された時の分腎尿 activator では健・患側ともに初回に比して低下をみせて招り， 更に投薬 1 週後に全く止血効果を認めた時は膀胱尿 ac tivator であるが更に低下して18 $\mathrm{mm}^{2}$ を示していた。 症例11は ஃ-ACA 1 日量 $8 \mathrm{~g}$ で 2 週間計 $112 \mathrm{~g}$ の投与で 止血效果を認めた時の膀胱尿 activator は36 $\mathrm{mm}^{2}$ て あり，その後投薬を中止して 1 週間後に軽度の血尿を来 し再度分腎尿 activator の検索を行了と初回の分腎尿 activator の程度よりは小であるが健側及び患側も立 進しているととが認められた。

3）他疾患々者の分腎尿 activator について(表 5) : 表に示す如く左右差は殆ど認められない.

4）血尿に於て血液成分特に血漿と尿中 activator と の関係(表 6 )：血尿の activator 測定に際し血漿中に 含まれる plasminogen や activator が本来の尿中 activator と如何なる 関係にあるか子検する目的で以下の 実験を行つた.

1）Urokinase（昭和薬品化工株式会社）倍々稀釈 蒸溜水で行い 1 cc中の単位が50単位から0.19単位まで 9 系列をつくり各 $5 \mathrm{cc}$ 入れて血槳( ${ }^{1} / 10 \mathrm{~N}$ 苳酸ソーダを ${ }^{1} / 10$ 容加えた血液を 3000 回転15分行つて得た）を夫々に 1 滴 づ〉滴下しよく混和振蕰して，これを標準平板及び加熱 板上に括として線溶面積を測定した. 表に示す如くUrokinase の活性が高いもの程標潐平板で線溶面積が大で ある.しかし加熱平板では全例線溶を認めない.

2) 次に Urokinase $1 \mathrm{cc}$ 中に 2 単位含を稀釈液を 6 本扮き 1 本を対照とし他を上記血漿を 1 滴・ 2 滴・ 4 滴・ 8 滴・16滴と夫从に滴下してよく混和抎蕰しててれ 
表 4 特特性腎出血の分腎尿 activator, anti-Plasmin

\begin{tabular}{|c|c|c|c|c|c|c|}
\hline 症例 & 氏 & 性 & 年令 & 測定項目 & 健 & 患 \\
\hline 1 & 寺 $\bigcirc$ & $\hat{o}$ & 52 & $\begin{array}{l}\text { act, } \\
\text { anti-PL }\end{array}$ & $\begin{array}{l}315 \\
104 \text { (左) }\end{array}$ & $\begin{array}{r}502 \\
44 \text { (右) }\end{array}$ \\
\hline 2 & 成 $\bigcirc$ & $\hat{o}$ & 37 & $\begin{array}{l}\text { act. } \\
\text { anti-PL }\end{array}$ & 228 (右) & $\begin{array}{l}361 \\
154 \text { (左) }\end{array}$ \\
\hline 3 & 上 $\bigcirc$ 野 & $\hat{o}$ & 22 & $\begin{array}{l}\text { act. } \\
\text { anti-PL }\end{array}$ & $\begin{array}{l}410 \text { (左) } \\
172 \text {. }\end{array}$ & 506 (右) \\
\hline 4 & 大 & $\hat{o}$ & 56 & $\begin{array}{l}\text { act. } \\
\text { anti-PL }\end{array}$ & 261 (右) & $\begin{array}{l}841 \text { (左) } \\
261 \text {. }\end{array}$ \\
\hline 5 & 柴 & $\hat{o}$ & 53 & $\begin{array}{l}\text { act. } \\
\text { anti-PL }\end{array}$ & 196 (右) & $\begin{array}{l}529 \\
295 \text { (左) }\end{array}$ \\
\hline 6 & 林 & $\hat{o}$ & 31 & $\begin{array}{l}\text { act. } \\
\text { anti-PL }\end{array}$ & $\begin{array}{l}281 \\
172 \text { (右) }\end{array}$ & $\begin{array}{l}541 \text { (左) } \\
230\end{array}$ \\
\hline 7 & 笠 & 우 & 21 & $\begin{array}{l}\text { act. } \\
\text { anti-PL }\end{array}$ & $\begin{array}{l}529 \text { (右) } \\
220\end{array}$ & $\begin{array}{l}756 \text { (左) } \\
282 \text {. }\end{array}$ \\
\hline 8 & 岡 & $\hat{o}$ & 34 & $\begin{array}{l}\text { act. } \\
\text { anti-PL }\end{array}$ & $\begin{array}{l}4004 \text { (左) } \\
264\end{array}$ & $\begin{array}{l}576 \\
306 \text { (右) }\end{array}$ \\
\hline 9 & 0 & P & 26 & $\begin{array}{l}\text { act. } \\
\text { anti-PL }\end{array}$ & 242 (右) & $\begin{array}{l}484 \text { (左) } \\
289\end{array}$ \\
\hline 10 & $\begin{array}{l}\text { 上 } \\
\mathbf{R}(\mathrm{H})\end{array}$ & $\hat{0}$ & 25 & $\begin{array}{l}\text { act. } \\
\text { anti-PL }\end{array}$ & $\begin{array}{l}301 \\
230 \text { (右) }\end{array}$ & $\begin{array}{l}529 \text { (左) } \\
295\end{array}$ \\
\hline $10^{\prime}$ & $\begin{array}{l}\text { 上 } \\
\mathrm{R}(+)\end{array}$ & $\hat{o}$ & 25 & $\begin{array}{l}\text { act. } \\
\text { anti-PL }\end{array}$ & $\begin{array}{l}138 \text { (右) } \\
168 \text {. }\end{array}$ & $\begin{array}{l}529 \\
169 \text { (左) }\end{array}$ \\
\hline $10^{\prime \prime}$ & $\begin{array}{l}\text { 上 } \\
\mathrm{R}(-)^{0}\end{array}$ & $\hat{o}$ & 25 & $\begin{array}{l}\text { act. } \\
\text { anti-PL }\end{array}$ & \multicolumn{2}{|c|}{$\begin{array}{l}18 \text { (両側合 } \\
225 \text { して) }\end{array}$} \\
\hline 11 & $\begin{array}{l}\text { 佐 O間 } \\
\mathrm{R}(\text { 州) }\end{array}$ & $\hat{o}$ & 23 & $\begin{array}{l}\text { act. } \\
\text { anti-PL }\end{array}$ & $\begin{array}{l}165 \text { (右) } \\
120\end{array}$ & 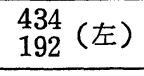 \\
\hline $11^{\prime}$ & $\begin{array}{l}\text { 佐 } \bigcirc \text { 間 } \\
\mathrm{R}(\text { (一) }\end{array}$ & $\hat{o}$ & 23 & $\begin{array}{l}\text { act. } \\
\text { anti-PL }\end{array}$ & \multicolumn{2}{|c|}{$\begin{array}{l}36 \text { (両側合 } \\
46 \text { 乙它) }\end{array}$} \\
\hline $11^{\prime \prime}$ & $\begin{array}{l}\text { 佐 ○間 } \\
\mathrm{R}(+)\end{array}$ & $\hat{\delta}$ & 23 & $\begin{array}{l}\text { act. } \\
\text { anti-PL }\end{array}$ & $\begin{array}{r}144 \text { (右) } \\
\end{array}$ & $\begin{array}{r}341 \\
89 \text { (左) }\end{array}$ \\
\hline
\end{tabular}

表 5 他疾患の分腎尿 activator 及び antiplasmin について

\begin{tabular}{|c|c|c|c|c|c|c|c|c|}
\hline 番号 & 姓 & 名 & 性 & 年令 & 疾 患 名 & $\begin{array}{l}\text { activator } \\
\text { anti-PL }\end{array}$ & 左 & 右 \\
\hline 1 & 柏 & 0 & $\delta$ & 27 & 右水腎症 & $\begin{array}{l}\text { act } \\
\text { anti-PL }\end{array}$ & $\begin{array}{r}25 \\
169\end{array}$ & $\begin{array}{r}26 \\
196\end{array}$ \\
\hline 2 & 天 & 0 & $\hat{o}$ & 53 & $\begin{array}{l}\text { 右不完全 } \\
\text { 重複尿管 }\end{array}$ & $\begin{array}{l}\text { act } \\
\text { anti-PL }\end{array}$ & $\begin{array}{r}51 \\
289 \\
\end{array}$ & $\begin{array}{r}60 \\
239 \\
\end{array}$ \\
\hline 3 & 渡 & 0 & o & 17 & $\begin{array}{l}\text { 神释因性 } \\
\text { 膀脱 }\end{array}$ & $\begin{array}{l}\text { act } \\
\text { anti-PL }\end{array}$ & $\begin{array}{r}59 \\
225\end{array}$ & $\begin{array}{r}49 \\
255\end{array}$ \\
\hline 4 & 野 & 0 & s & 77 & 膀脱腫瘍 & $\begin{array}{l}\text { act } \\
\text { anti-PL }\end{array}$ & $\begin{array}{r}89 \\
180 \\
\end{array}$ & $\begin{array}{r}81 \\
160 \\
\end{array}$ \\
\hline 5 & 玄 & 0 & o & 28 & 両㑡水腎症 & $\begin{array}{l}\text { act } \\
\text { anti-PL }\end{array}$ & $\begin{array}{l}120 \\
156\end{array}$ & $\begin{array}{l}120 \\
168\end{array}$ \\
\hline 6 & 菅 & 0 & $\hat{0}$ & 31 & 右腎孟結石 & $\begin{array}{l}\text { act } \\
\text { anti-PL }\end{array}$ & $\begin{array}{l}165 \\
220 \\
\end{array}$ & $\begin{array}{l}190 \\
210\end{array}$ \\
\hline 7 & 余 & 0 & 우 & 51 & 左尿管結石 & $\begin{array}{l}\text { act } \\
\text { anti-PL }\end{array}$ & $\begin{array}{r}140 \\
49\end{array}$ & $\begin{array}{l}144 \\
134\end{array}$ \\
\hline 8 & 池 & 0 & 우 & 32 & 右腎孟腎炎 & $\begin{array}{l}\text { act } \\
\text { anti-PL }\end{array}$ & $\begin{array}{l}240 \\
370\end{array}$ & $\begin{array}{l}246 \\
382\end{array}$ \\
\hline 9 & 高 & 0 & 우 & 54 & （両側）囊胞腎 & $\begin{array}{l}\text { act } \\
\text { anti-PL }\end{array}$ & $\begin{array}{l}272 \\
336\end{array}$ & $\begin{array}{l}233 \\
226\end{array}$ \\
\hline
\end{tabular}


表

6

1）Urokinase の倍々稀釈した系列各 5 cck血獎を 1 滴づつ滴下, 混和したものの線溶

（標準平板）

\begin{tabular}{|c|c|c|c|c|c|c|c|c|c|}
\hline & 1 & 2 & 3 & 4 & 5 & 6 & 7 & 8 & 9 \\
\hline 1 cc中の Urokinas の単位 & 50 & 25 & 12.5 & 6.25 & 3.12 & 1.56 & 0.79 & 0.39 & 0.19 \\
\hline 溶 解 面 樍 $\mathrm{mm}^{2}$ & 884 & 795 & 675 & 564 & 517 & 358 & 279 & 182 & 105 \\
\hline
\end{tabular}

(加熱平板では全例 $0 \mathrm{~mm}^{2}$ )

2) Urokinase $2 \mathrm{~V} / \mathrm{cc}$ を含む系列名 $5 \mathrm{cck}$ 血漿を滴下混和振蕰したものの線溶

(標隻平板)

\begin{tabular}{|rc|c|c|c|c|c|c|}
\hline 血 & 槳 滴 $\mathrm{F}$ 数 & 対 照 & 1 滴 & 2 滴 & 4 滴 & 8 滴 & 16 滴 \\
\hline 溶 & 解 \\
\hline
\end{tabular}

（加熱平板では全例 $0 \mathrm{~mm}^{2}$ )

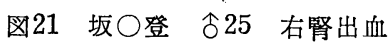

\begin{tabular}{|c|c|c|c|}
\hline $\begin{array}{ll}R: 442 \times 10^{4}, & H L \\
W: 8200(1), & P l\end{array}$ & $\begin{array}{l}\text { Hb: }: 84 \% \\
\text { Plat: } 21 \times 10^{4}\end{array}$ & $\begin{array}{l}\text { プロトロンビン時间 } \\
\text { 血 沈 } 2 \mathrm{~mm} / 1 \text { 時间, }\end{array}$ & $\begin{array}{l}12 \text { 秒 (92\%) } \\
\text { 肝機能 (硫亚) } 6.5\end{array}$ \\
\hline & 7/正尛 & $21 /$ VII & $3 / /$ VII \\
\hline Hematuria & $(t) \downarrow$ & $\varepsilon \cdot A C A 6 g \times 6^{( \pm)} 36 g$ & $(+)$ \\
\hline Fibrinogen & $\mathrm{mg} / \mathrm{dl} \quad 250$ & 330 & 200 \\
\hline Plasma & $\mathrm{mm}^{2} \quad 0$ & 0 & 0 \\
\hline$H \cdot E \cdot$ & $\mathrm{mm}^{2}, 100$ & 0 & 90 \\
\hline$H \cdot E \cdot+S K$ & $\mathrm{~mm}^{2}$ & 928 & $\stackrel{1099}{\longrightarrow}$ \\
\hline$P l+S K$ & $\mathrm{~mm}^{2} \stackrel{928}{2}$ & 830 & 813 \\
\hline Anti-PL & $\mathrm{mm}^{2} \quad 672$ & 770 & 540 \\
\hline 层 Activator & ir $\mathrm{m} \mathrm{m}^{2} \frac{455}{327}$ & 35 & 210 \\
\hline 尿Anti-PL & L $\quad \mathrm{mm}^{2} 327$ & 610 & 168 \\
\hline
\end{tabular}

を標準及び加熱平板上に掠とした．表に示す如く対照に 比して, 滴下数の增加につれて標準平板上では線溶面積 が小となつて抢り加熱平板では全例線溶を示さない。以 上の基礎実験 から 尿中 activator が大なる時㤌線溶面 積恃大となり, 尿中の血液成分特に血槳の量には影響安 ろけず，むしろ inhibitorの作用が現れて血漿成分が 多いと線溶面積は却つて小となることが明かであ.

[X] 他疾患混入例及び疑問のある例

症例 1 （図21）は25才男子. 初診時中等度の血尿を主 訴とし, 膀胱内景では右尿管口ょりの血尿を認める以外 に異常なく青排泄も両側とも正常, 腎部膀腅部単純撮影 及び排泄性腎孟撮影であ正常であり,その他の諸検査て
も異常を認めず刃㿡生検でも異常所見はみられず本疾患 と診断された。図に示す如く線溶能はかなりの充進を示 していた. そとで $\varepsilon$-ACA 1 日量 $6 \mathrm{~g}$ が 6 日間計 $36 \mathrm{~g}$ 投 与された時の線溶系各因子は改善を示し尿中 activator も $35 \mathrm{~mm}^{2}$ を示すようになり“尿所見む赤血球が全視野 で 1 ないし 2 ケの状態となり計 $42 \mathrm{~g}$ 投与後に退院した. その後投薬を中止して退院後11日目の線溶系各因子は図 の如くで再びかなりの克進を示し尿中 activartor の増 強を見, 尿所見も軽度の血尿を示した. その後来院せず 約 6 ケ月後に他病院で排泄性腎孟撮影で異常を認められ 右腎腫瘍の診断の下に腎剔除術が行われ腺腫々診断が磪 定した例である. 症例 2 （図22）は52才男子. 血尿を主 
叉22 宮○卓○令52 左腎出血

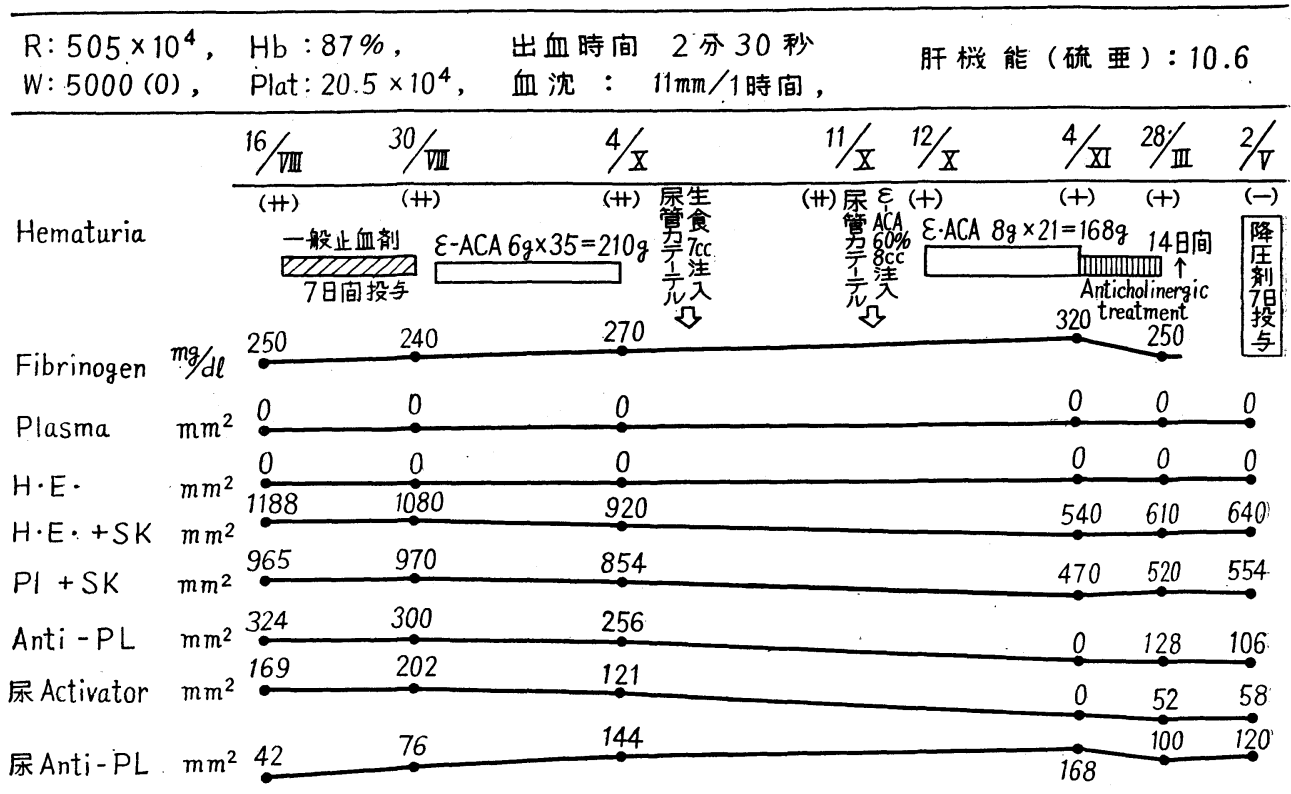

訴として約 3 ケ月他病院に入院し一般的止血剤の投与を ろけたが効果なく最高血圧 $200 \mathrm{~mm} H \mathrm{Hg}$ 最低血圧 $100 \mathrm{~mm} \mathrm{Hg} の$ 高血圧を指摘された，その間頻回に行われた腎膀胱部単 純撮影, 排泄性腎孟撮影及び逆行性腎孟撮影でも異常を 認めない. その後当科を訪れた. 膀胱内景には左尿管口 よりの血尿を認める以外に異常なく青排泄も両側正常, 腎部膀胱部単純撮影排泄腎孟撮影も初回以来の像と同じ で異常を認めない. 最高血圧 $209 \mathrm{~mm} \mathrm{Hg}$ 最低血圧 $90 \mathrm{~mm} \mathrm{Hg}$ の 高血圧を認め, 心電図所見でも左心肥大を認めるが血算 血液化学でも異常を認めず全身的な出血傾向も認められ ない. 図に示す如く線溶系各因子は著しい充進を示して いる. そこで $\varepsilon-\mathrm{ACA} 1$ 日量 $6 \mathrm{~g}$ が 5 週間投与されたが 止血効果を見ず, 逆行的に尿管カテーテリスムスにより $60 \% \varepsilon-\mathrm{ACA}$ を $8 \mathrm{cc}$ 腎㙉内に注入し更に経口的に $\varepsilon-\mathrm{ACA}$ 1 日量 $8 \mathrm{~g}$ が 3 週間に亘つて投与された時の線溶系各 因子は著しい改善を示し特に尿中 activator は $0 \mathrm{~mm}^{2}$ を示すが依然として軽度の血尿（ $400 \times 1$ 視野に10ケ の赤血球)を認めるものであり更に anticholinergic treatment も奏効せず，その後の排泄性腎孟撮影でも全 く異常を認めず心電図所見より大量の $\varepsilon-\mathrm{ACA}$ の投与泣 好染しくないので投与を中止して降圧剤を 1 週間使用す ると血尿は消失し血圧は $178 \mathrm{~mm} \mathrm{Hg} \sim 80 \mathrm{~mm} \mathrm{Hg}$ となり目下経 過観察中である.

[XI] 考按
特発性腎出血に関しては古くょり先人にょり種くの要 因が挙げられている，本疾患に関して一元的に定義づけ るととは不可能であり，はじめに述べたように一症候群 として解釈すべきであるが本論交に於で柱酵素学的な面 から本疾患を眺めその病態生理の一端を解明しょうとと 〉ろみた。

1) 自律神経系との関係. Klemperer $(1897)^{14)}$ が Angioneurotische Blutung 唱え Broca (1894) ${ }^{5)}$, Casper $(1906)^{9)}$ Recklinghausen, Santini, Brownsequard, Ebstein, Neubürger (1927), ${ }^{25)}$, Borsotti (1937 ${ }^{29)}$ らも血管運動神経異常による出血を唱え，血管麻疩説 或いは血管刺战説により説明せんとし, Rieder (1933), ${ }^{9}$, Junker (1944), ${ }^{13 »}$, Wildbolz (1953) ${ }^{439}$ らは腎に入 る神経の剥離ないし切断による治験例を報告している. 本邦では稲田 $(1958)^{455}$ 蔡 $(1958)^{56)}$, 小川 岡本 $(1958)^{501}$, 仁平 $(1959)^{61)}$, 笠井 $(1960)^{521}$ らの 報告があり，夫々に自律神経遮断剤により治療せしめた 興味ある症例について述べられているが現在では視床下 部を含めた全自律神経系買常との関連について検討され ている.

2) Allergy ないし Anaphylaxy との関係.

Osler (1914) ${ }^{26)}$ の報告に初まり Mac Gowan (1923i)， ${ }^{20)}$, Adelsberger (1931) ${ }^{1)}$, Tzanck \& Cottet (1934) ${ }^{38)}$, Rhodes (1937) ${ }^{31)}$, Miller \& Uhle (1939) ${ }^{22)}, \mathrm{Th}$ - 
omas \& Wicksten (1949) ${ }^{399}$, Eisenstaedt (1951) ${ }^{10)}$ らの報告があり, 本邦では高安(1955) ${ }^{59)}$, 原田(1959), ${ }^{62)}$ 伊藤 (1959) ${ }^{46)}$ の報告 が夕られ又 Randall (1933) ${ }^{30)}$ の病巣感染との関係についての発表以来 Wilbur \& Priestley (1935) ${ }^{41)}$, Alken (1952) ${ }^{31}$, Heine (1953) ${ }^{12)}$ の報告が述べられ，馬杉 (1948) ${ }^{66}$ は病巣感染と腎炎々 の間に Allergy 機序の存在を述べ, 岡林 $(1950){ }^{49}$ の 実験的研究 があり, Finkle $(1954)^{11}$, 仁平 $(1958)^{60)}$, 島本 (1959） ${ }^{57)}$ の扁桃腺と腎出血との関連についての報 告がなされている. 即ち Allergy ないし Anaphylaxy の発現機序に関しては抗原抗体反応にあるここは勿論で 作用物質としては Histamin, Histamin 様物質, Acetylcholine, Kinin, Bradykinin, Serotonin, ATP が挙 げられているが腎出血との関連に於ては專ら Histamin Histamin 様物質の問題に努力がむけられていた。

3) Acetylcholine-Cholinesterase 系と腎出血. 杉 浦 (1962) ${ }^{58)}$ の既に詳細に述べた如く産婦人科領域に於 ける月経出血についての Okkels (1950) ${ }^{27)} の$ 説即ち 子宮内膜コイル動脈の 終末部と静脈湖との間に動静脈 伆合が存在し Acetylcholine によりこの動静脈吻合が 開大し動脈及び表層近接部の毛細管内の血液がこれを通 つて直接静脈湖に流入する為内膜表層恃賀血状態に打与 いる. 湖から出る聚合静脈は波状を描くため血流は遜滞 し又直接本動脈からの動脈圧をうりるので血液は血管周 曲に逸出し排出される。乙れが月経であると説明してい る.一方腎の血管構成に関しては Spanner (1937) ${ }^{33}$ 隹墨汁注入標本を用いて腎盂間質被膜の部に動静脈吻合 が比較的高率に認められる事を, 又 Simkin (1948) ${ }^{35)}$ は鬼で腎動脈に注入した直径50ないし $180 \mu$ のガラス球 が腎静脈より回収されるととを, 人の屍腎の潅流実験で 直径 90 ない $440 \mu$ のガラス球の通過が認められるとと から動静脈吻合の存在を唱えた。他方 Shonyo \& Mann (1944) ${ }^{34)}$ 忙 Neplon cast 用い犬の実験で, 又 Treuta も Spanner の追試を行いその存在を否定, 腎典 の部では小葉間動脈から婜孟へコイル状に動脈がのびる が Spanner はこれを動静脈吻合と混同したのではない かと述べ, More (1950) ${ }^{24)}$ も腎で Castを用いた実験 で動静脈吻合の存在を否定している. 江口 (1958） ${ }^{47)}$ アクリル樹脂 Cast を用いててれを認めないが, $\mathrm{Mc} \mathrm{Ca}$ llum (1935) ${ }^{211} の い う$ non-glomerular arteriole の多 いことを示している. 長谷川 (1960) ${ }^{63)}$, 黒田 (1962)

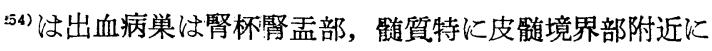
多く各腎の出血性変化を伴う腎杯は 1 ないし 2 ケに限ら
れ部位的特異性はないが何れも該部に至る螺旋動脈の血 行障碍による腎杯壁の組織変性を重視している. 即ち機 能的子宮出血にみられる内膜コイル動脈の痤孪性収縮己

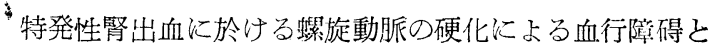
の両者の類似性より杉浦は本疾患に上記の如き anticholinergic treatment 学行い56.4\%完全止血昰改て, Cholinesterase 系の異常による腎出血学確認したのて ある.

4）線溶系之婜出血.

a) 自律神経系と線溶系. Macfarlane (1947) ${ }^{23}$ 蚁精 神的心理的動摇の際に又古島 (1957) ${ }^{65)}$, 畔柳 (1960) ${ }^{53)}$ 万屾 Adrenalin 注射時に線溶の起ると已学認內, 自 律神経系上線溶系の間には密接な関係が㟔るととが琶为 られている。

b) Allergy ないし Anaphylaxy と線溶系. Rocha e Silva $(1946)^{322}$ 快蛋白分解醰素によつて Anaphylaxy を起す物質が遊離されるととを trypsin について報告 し, Plasmin 活性が allergy 及び Anaphylaxy 発 現の要因であるとし, Ungar (1947) ${ }^{40)}$ は感作された 動物に対応抗原接触せしめると plasmin が活性化 されるととを述べ, 岡本 (1950) ${ }^{48}$ 快 plasmin によ る分解産物が Acetylcholine 様作用定も5, 肺肝安 蛋白分解醭素で潅流する時に Histamin が逝離するな ぞ plasmin を媒介として Anaphylaxy 発現に関与す る物質の生成を示している.

c) Kawwan (1957, 1958) 15)16117) 万注前膊静脈安 用いる実験で Histamin, Serotonin, Adrenalin Atropin,Acetylcholine などの注射時又は anoxia, ischemia の封に 静脈壁又は動脈壁の cholinergic effector に作 用して plasmin が活性化されることを示した。

双て尿中 plasminogen activator 即与所謂 Urokinase については Williams (1951) ${ }^{422}$, Astrup \& Sterndorff (1952), ${ }^{2)}$, Sobel (1952) ${ }^{37)}$ によつ夫火他詳細 な報告があり, Bjerrehuns (1952) ${ }^{7)}$ 仗 Urokinase 活 性について膀胱尿, 腎孟尿についても差のないとと字 述べ, Smyrniotis ら (1959) ${ }^{36)}$ 仙正常人の Urokinase

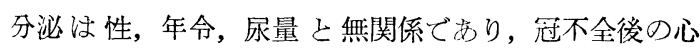
筋障碍発作時に圥等り, 癌疾患, 概血性心不全, 尿毒症 の時低下すること定述べている。

von Kaulla (1961) ${ }^{187}$ 万あ癌末期飞 Urokinase 分 泌が低下することを述べている. Urokinase の生理的 役割として尿路に於ける Fibrin 及び㠜血の速やかな溶 解作用が現在では㞻識的な兒解とされているが von K- 
auila $は$ Urokinase の分泌を腎機能を反映するものと 解し，心筋障碍発作やレ線全身照射等にその分泌の上 昇するととにより，Urokinase 以血嶈 activator の分 泌されたもので尿路上皮細胞功の分泌を否定してい" る. 然し Astrup \& Sterndorff は単なる血漿からの分 泌産物でなく䅽で生成されたものを含むと主張してい る. 一力 Buluk \& Furman (1961) ${ }^{8)}$ は動物実験及び 5 人の手術例で腎動静脈の採血により線溶時間測定法で 静脈血に plasmin 活性の高いととを述べ, 腎の activator 産生が循環血中への分泌をも伴つているととを述 べている.最近 Ladehoff (1962) ${ }^{19}$ は腎腫瘍及び膀胱 腫瘳の組織 activator について検索し, 腫痬組織 activator 结健常組織 activator よりも低い傾向にあるこ とを示し又正常腎組織では䯑道質部が皮質部よりも高い activator 活性を有するととを述へている. 叉 Painter (1962) ${ }^{28)}$ らは腎組織培養液の activator 検索を行い 電気泳動法により組織 activator よりもむしろ組織培 羕液中の activator がょり Urokinase に似ていると とを述べ urokinase の origin について推論している. 現在安で $\varepsilon$-ACA による本疾患治嘹の報告は算野 (1961) 64) 万が33例の本疾患々者血漿について線溶時間測定法 て plasmin 活性を示したもの26例 $(78.7 \%)$ をみて, その 20 例々本療法を行い有効 13 例, 無効 7 例と述べ本療 法㹥速效性であるため，1 クール（1ｇ/日静注を７な (し10日)で血尿の消失しないものに対しては他の治療 法走行う必要があると報告している。河野 (1962) ${ }^{55}$ 注 家乐を用いる実験で腎神経丵刺战法, 頝静脈襄法, 腹 腔神経節刺战法によつて腎出血を起させた動物の血槳 plasmin 值の上界及び腎静脈血が頝静脈血より plasmin 活性の高いとと又患側腎の方が健側腎よりも鼻粘膜腺溶 能を強く抑制するとと更に腎組織の tissne activator は Reilly 現象により多少促進する傾向のあるととを述 べている.一方 Andersson (1962) 4) は 3 例の本疾患々 者の $\varepsilon$-ACA 療法による治験例を報告している. 我及は 39例の木疾患々者の線溶系各因子の六進を認め, $\varepsilon-\mathrm{ACA}$ により 36 例 $(92.3 \%)$ 飞完全止血を認め本治療により推 計学的考察を行い（表 1) 完全止血例に於ては線維素原 量, Euglobnlin + Strepiokinase の溶解面積, 血漿十 Streplokinase の溶解面積, 抗 plasmin 值, 尿中 activator 及び抗 plasmin 值について夫く $5 \%$ 危険率を以 て有意の差を認め本治療法の有用なるととを確認した。 又本疾患从者は正常人に比して尿中 activator が高值 を示し尿管カテーテリスムスを行い他疾患に於ては分腎 尿 activator に差を認めず本疾患に於ては患側腎尿に activator の高値なととを認め治療によつて activator の低下と共に止血効果を認め又一方手術時腎動静脈血の: 採血標本の線溶系の比較からも Astrnp \& Sterndorff, Buluk らの述べる如く腎局在性の activator 産生を確 認し少数例に逆行的に高濃度 $\varepsilon-\mathrm{ACA}$ 注入を腎孟内に行: い止血効果を得たことから本疾患の一面を䶤局在性 acivator ないし腎尿 activator の異常充進を之の主因 と考えるものである. 又尿中 activator の日内変動を みてその変動の小なるとと及び少数例ながら夜間高值 型，昼閒高値型の二型を認めた。一方血尿㭙に血漿中 activator の尿中移行による尿中 activator の影響安 検する基礎実験（表 6 ）を行い却つて血獎中抗 plasmin 值の作用を認めて, 本疾患々者尿中 activator 高値の ことを確認した. Ladehoff の述べる如き正常部腎組織: に於て皮質部小りも䯣質部に activrator の高值なるこ とは腎の血管構築と共に血尿の発生機序として興味ある 点であり少数例ながら我々も同様の結果を得て居りこの ことについては別著に発表する予定である. Acetylcholine, Serotonin Histamin などが plasmin によつて 生じた分解産物なる観点からみれU゙線溶系と Cholinesterase 系が平行関係を有するととは理解されるのであ るがその相互の作用機序に関しては Kawwan らのいう, Cholinergic effector mechanism をむ含めて今後の検 討に期待されるであらう. 然し何故片側に血尿を来すか 及び季節的な外因などの問題は自律神経及び他の酵素系 を含めた複雑な諸因子の上にたつ検索が必要であると考 えられる。

〔XII]結語

1） 39 例の本疾患々者を $\varepsilon-\mathrm{ACA}$ 投与（大量投与がよ り治療効果が大）により 36 例 $(92.3 \%)$ に完全止血をみ た.

2）本疾患に於ては線溶系各因子の卋進をみるがその 治療上の指標としては尿中 activator の検索が最も有 用である.

3）本疾患々者の分腎尿 activator に於ては患側腎 尿に高值なるととを認めたた。

4）尿中 activator は 日内変動を示すが夜間高值型 と昼間高值型の二型を認め何れもその変動は小であり任 意の時点の測定が可能である.

5）腎局在性 activator の産生を筒動静脈血の線溶 系より確認した。

6）尿中 activator は血尿時に於ても血獎 activator の影響のないととを認めた。

7) 線溶系と Cholinesterase 系の平行関係を認奴 た。 
図表中の略号は以下の如くである.

Fib $\longrightarrow$ Fibrinogen, 単位mg/dl

$\mathrm{Pl} \longrightarrow$ Plasma

H.E. $\longrightarrow$ Human Euglobulin

SK $\longrightarrow$ Streptokinase

Anti-PL $\longrightarrow$ Anti-Plasmin

Act $\longrightarrow$ Activator

単位は $\mathrm{mm}^{2}$ の面皘を表吉。

稿を終るに臨み終始御指導と御校閲を賜つた恩師市川 篤二教授に深謝いたします。尚本論文の要旨は昭和 37 年 10 月, 日本泌尿器科学会第 27 回東部連合地方会に於いて 発表した。

\section{文献}

1) Adelsberger, L.: Deut. med. Wschr., 57, $585,1931$.

2) Astrup, T. \& I. Sterndcrif: Proc. Soc. Exper. Biol. \& Med., 81, 675, 1952.

3) Alken, C.F. et al: Z. Urol., 45, 665, 1952.

4) L. Andersson: Acta Chir. Scand., 124, 355, 1962.

5) Broca: Ann de male de org. genit-urin., 881, 1894.

6) Borsotti, P.C.: Z. Urol. Chir., 43, 314, 1937.

7) Bjerrehuns, I.: Scand. J. Clin. Lab. Invest., 4, 179, 1952.

8) K. Buluk, \& M. Furman: Exper., 18, 146, 1961.

9) Casper: Arch. Klin. Chir., 80, 350, 1906.

10) Eisenstaedt, J.S.: J. Urol., 65, 154, 1951.

11) Finkle, A.L. et al.: J. Urol., 72, 111, 1954,

12) Heine, J.: Z. Urol., 46, 247, 1953.

13) Junker: Z. Urol., 42, 432, 1949.

14) Klemperer: Dtschr. med. Wschr., 128, 1897.

15) Kawwan, H.C. et al.: Clin. Sci., 16, 255, 1957.

16) Kawwan, H.C. et al.: Brit. J. Haematol., $4,51,1958$.

17) Kawwan, H.C. et al.: Clin. Sci., 17, 361, 1958.

18) Von Kaulla: Cancer, 14, 889, 1961.

19) A.A. Ladehoff: Acta path. Microbiol. Scand., 55, 273, 1962.

20) Mac Gowan: J. Urol., 9, 331, 1923.

21) Mc Callum, D.B.: Am. J. Anat., 65, 69, 1935.

22) Miller \& Uhle: Int. Clin., 3, 183, 1939.

23) Macfarlane, R.G. \& Biggs, R.: Lancet, 1, $402,1947$.

24) More, R.H.: Am. J. Path., 27, 95, 1950.

25) Neubürger, K.: Arch. f. Path. Anat., 265, $789,1927$.
26) Osler: 泌尿器科全書より引用.

27) Okkels, H.: Engl. editor Menstruation \& its disease, 1950.

28) R.H. Painter \& A.F. Charls: Am. J. Physiol., 202, 1125, 1962.

29) Rieder: Arch. Klin. Chir., 177, 618, 1933.

30) Randall, A.: J. Urol., 37, 735, 1933.

31) Rhodes, J.: J. Urol., 38, 40, 1937.

32) Rocha e Silva, M. et al.: Am. J. Physiol., 156, 26, 1946.

33) Spanner, R.: Klin. Wochenschr., 16, 1421, 1937.

34) Shonyo, E.S. \& Mann, F.C.: Arch. Path., 38, 287, 1944.

35) Simkin, B.: Arch. Int. Med., 81, 115, 1948.

36) Smyrniotis, F.E. et al.: Thromb. et Hemorrhag. in Press (Physiol. Rev., 39, 343, 1959より引用）

37) Sobel, G.W. et al.: Am J. Physiol., 71, 768, 1952.

38) Tzanck, A. \& Cottet, J.: Presse méd., 42, 415, 1934.

39) Thomas, L. et al.: Ann. Allergy, 2, 396, 1949.

40) Ungar, G.: Lancet, 2, 708, 1948.

41) Wilbur, D.L. et al.: Ann Surg., 101, 647, 1935.

42) Williams, J.R.B.: Brit. J. Exper. Path., 32, $530,1951$.

43) Wildbolz, E. et al.: Monatsschr. Unfallh., $58,86,1953$.

44)市川：綜合臨床，9, 108, 1960 .

45) 稲田他：最新医学, 6, 133, 1951.

46) 伊藤：日泌尿会誌, $50,838,1959$.

47) 江口：日病理会誌， $47,323,1958$.

48) 岡本: 生物科学, $2,55,1950,3,97,1950$.

49) 岡林: 日本臨床, $8,30,1950$.

50) 岡本：日泌尿会誌, $49,294,1958$.

51）小川：日泌尿会誌, $50,75,1959$.

52）笠井：日泌尿会誌， 51， 1223， 1960.

53) 畔柳：臨床血液, $1: 5,1,1960$.

54）黑田：日泌第27回東部連合地方会で 発表, 1962.

55）河野：日泌尿会誌, 53, 179, 1962 .

56) 蔡他: 臨皮泌, 12, 145, 1958.

57) 島本：日泌尿会誌, $50,728,1959$.

58）杉浦：日泌尿会誌, 54, 263, 1963.

59) 高安: 最新医学, 10, 1195, 1955.

60) 仁平: 泌紀要, $4,483,1958$.

61) 仁平: 泌紀要, 5, 19, 1959.

62 ) 原田 : 日本医事新報, 1856, 3, 1959 .

$63)$ 長谷川。 日泌尿会誌, $51,872,1960$.

64）砤野他：臨皮波, 15, 105, 1961.

$65)$ 古島 : 最新医学, 12,194, 1957.

66) 馬杉：腎炎その他の研究 (寧楽書房), 1948.

$67 ）$ 米瀬他：日泌尿会誌，53，754, 1962.

(昭和 38 年 6 月 25 日受付, 特別提載) 